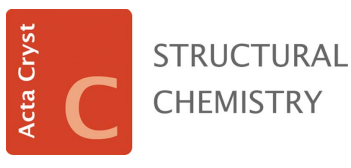

ISSN 2053-2296

Received 23 June 2016

Accepted 22 July 2016

Keywords: naproxen; picolinamide; cocrystal; NMR crystallography; DFT analysis; hydrogen bonding; crystal structure; pharmaceuticals; dimers; computational chemistry.

CCDC reference: 1495366

Supporting information: this article has supporting information at journals.iucr.org/C

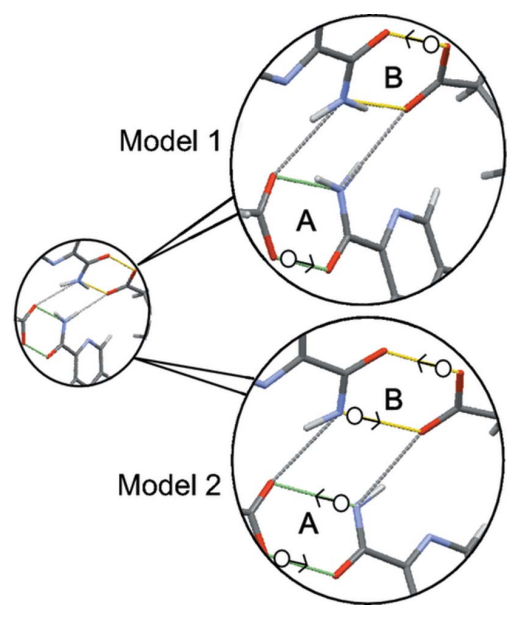

OPEN $\odot$ ACCESS

\section{Structure and physicochemical characterization of a naproxen-picolinamide cocrystal}

\author{
Hannah E. Kerr, ${ }^{a}$ Lorna K. Softley, ${ }^{a}$ Kuthuru Suresh, ${ }^{b}$ Paul Hodgkinson $^{\mathrm{a} *}$ and \\ Ivana Radosavljevic Evans ${ }^{\mathrm{a} *}$
}

${ }^{\mathbf{a}}$ Department of Chemistry, Durham University, Lower Mountjoy, Stockton Road, Durham DH1 3LE, UK, and ${ }^{\mathbf{b}}$ School of Chemistry, University of Hyderabad, Hyderabad 500 046, India. *Correspondence e-mail:

paul.hodgkinson@durham.ac.uk, ivana.radosavljevic@durham.ac.uk

Naproxen (NPX) is a nonsteroidal anti-inflammatory drug with pain- and feverrelieving properties, currently marketed in the sodium salt form to overcome solubility problems; however, alternative solutions for improving its solubility across all $\mathrm{pH}$ values are desirable. NPX is suitable for cocrystal formation, with hydrogen-bonding possibilities via the $\mathrm{COOH}$ group. The crystal structure is presented of a 1:1 cocrystal of NPX with picolinamide as a coformer [systematic name: $(S)$-2-(6-methoxynaphthalen-2-yl)propanoic acid-pyridine-2-carboxamide (1/1), $\left.\mathrm{C}_{14} \mathrm{H}_{14} \mathrm{O}_{3} \cdot \mathrm{C}_{6} \mathrm{H}_{6} \mathrm{~N}_{2} \mathrm{O}\right]$. The pharmaceutically relevant physical properties were investigated and the intrinsic dissolution rate was found to be essentially the same as that of commercial naproxen. An NMR crystallography approach was used to investigate the $\mathrm{H}$-atom positions in the two crystallographically unique $\mathrm{COOH}-\mathrm{CONH}$ hydrogen-bonded dimers. ${ }^{1} \mathrm{H}$ solid-state NMR distinguished the two carboxyl protons, despite the very similar crystallographic environments. The nature of the hydrogen bonding was confirmed by solid-state NMR and density functional theory calculations.

\section{Introduction}

Naproxen (NPX, Scheme 1), or (S)-2-(6-methoxynaphthalen2-yl)propanoic acid, is a nonsteroidal anti-inflammatory drug with pain- and fever-relieving properties, commonly used in the treatment of arthritis, dysmenorrhea and acute gout. NPX is a weak acid (DrugBank, accessed July 2016; Wishart et al., 2006), with a $K_{a}$ value of 4.2 , leaving it un-ionized in gastrointestinal fluids. It is formally classified as a low-solubility high-permeability drug (Takagi et al., 2006), but its solubility is highly dependent on the $\mathrm{pH}$ of the surrounding environment. The large hydrophobic aromatic region present in the molecule disfavours interactions with water molecules, and hence it is insoluble in aqueous media. In environments with higher $\mathrm{pH}$, such as in the membranes surrounding the cells, NPX becomes ionized, with the charged $\mathrm{COO}^{-}$group forming more favourable interactions with water, enhancing dissolution. To overcome the solubility problems, NPX is currently marketed in a salt form, i.e. naproxen sodium; however, alternative solutions for improving the solubility of NPX across all $\mathrm{pH}$ values are desirable.

NPX is suitable for cocrystal formation, with hydrogenbonding possibilities via the $\mathrm{COOH}$ group, which can form a range of one-, two- or three-dimensional robust synthons (Desiraju, 1995), with additional $\pi$-stacking interactions from the aromatic region. To date, 16 cocrystals of NPX have been synthesized and characterized using a variety of techniques, including X-ray diffraction (XRD), infrared (IR) spectroscopy and differential scanning calorimetry (DSC). Cocrystals with 
the following coformers have been reported: nicotinamide (NA), isonicotinamide (INA), picolinamide (PA) (Neurohr et al., 2015; Castro et al., 2011), trans-1,2-bis(pyridin-4-yl)ethylene (TBPE) (Weyna et al., 2009), duloxetine (Buschmann et al., 2009), tramadol (Buschmann et al., 2010), bipyridine (BPY) and piperazine (PPZ) (Manoj et al., 2014), and several chiral amino acids, including alanine (AL), zwitterionic prolinium (PR), tyrosine (TY), tryptophan (TP) and $\mathrm{N}$ octylglucamine (O-GL) (Tumanova et al., 2014; Tilborg et al., 2013; Yuan et al., 2001). The structures of many of these cocrystals have been determined using single-crystal diffraction (see footnote in Table 1). The relevant synthons are shown in Fig. 1 and summarized for all 16 reported cocrystals in Table 1.<smiles>COc1ccc2cc([C@@H](C)C(=O)O[Tl]CNC(=O)c3ccccn3)ccc2c1</smiles>

(S) NPX-PA<smiles>NC(=O)c1cccnc1</smiles>

NA<smiles>NC(=O)c1ccncc1</smiles>

INA<smiles>NC(=O)c1ccccn1</smiles>

$\mathrm{PA}$

Scheme 1

The coformers of five of the reported cocrystals contain a pyridine ring, which readily interacts with the carboxylic acid group on NPX (synthon $\mathbf{D}$ ). The importance of synthon $\mathbf{D}$ is further highlighted by observing the synthons present in cocrystals with the isomeric pyridinecarboxamides NA and INA coformers (see Scheme 1). The formation of synthon $\mathbf{D}$ in

A<smiles>[R]C(=O)OCOC([R])O</smiles>

D<smiles></smiles>

G<smiles></smiles>

Figure 1

Synthons present in the NPX cocrystals previously reported in the literature. Note that synthon B involves neighbouring INA molecules, and the NPX COOH group is involved in synthons $\mathbf{C}$ and $\mathbf{D}$.
Table 1

Synthons present in previously reported NPX cocrystals.

NA is nicotinamide, INA is isonicotinamide, TBPE is trans-1,2-bis(pyridin-4yl)ethylene, BPY is bipyridine, PPZ is piperazine, AL is alanine, TY is tyrosine, PR is zwitterionic prolinium, TP is tryptophan and O-GL is $N$-octylglucamine.

\begin{tabular}{|c|c|c|c|c|c|c|c|c|c|}
\hline & $\mathbf{A}$ & B & $\mathbf{C}$ & D & $\mathbf{E}$ & $\mathbf{F}$ & G & $\mathbf{H}$ & $\mathbf{I}$ \\
\hline$S-\mathrm{NPX}^{a}$ & * & & & & & & & & \\
\hline$S-2 \mathrm{NPX}-\mathrm{NA}^{b}$ & & & * & * & * & & & & \\
\hline$S$-NPX-INA ${ }^{b}$ & & * & $*$ & $*$ & & & & & \\
\hline$S$-NPX-TBPE ${ }^{c}$ & & & & * & & & & & \\
\hline$R S$-NPX-BPY ${ }^{d}$ & & & & $*$ & & & & & \\
\hline$S$-NPX-BPY ${ }^{d}$ & & & & $*$ & & & & & \\
\hline$R S$-NPX-PPZ ${ }^{d}$ & & & & & & * & & & \\
\hline$S$-NPX-PPZ ${ }^{d}$ & & & & & & $*$ & & & \\
\hline$S$-NPX-L-AL ${ }^{e}$ & * & & & & & & $*$ & & \\
\hline$S$-NPX-D-AL ${ }^{e}$ & $*$ & & & & & & $*$ & & \\
\hline$S$-NPX-D-TY ${ }^{e}$ & * & & & & & & * & & \\
\hline$S$-NPX-D-TP & * & & & & & * & * & & \\
\hline$S$-NPX-L-PR ${ }^{e}$ & * & & $*$ & & & & & & \\
\hline$S$-NPX-D-PR ${ }^{e}$ & * & & * & & & & & & \\
\hline$R S-\mathrm{NPX}-\mathrm{L}-\mathrm{PR}^{e}$ & $*$ & & & & & & & & \\
\hline$R S$-NPX-DL-PR ${ }^{e}$ & * & & * & & & & & & \\
\hline$S$-NPX-O-D-GL ${ }^{e}$ & & & & & & * & & $*$ & \\
\hline
\end{tabular}

References: (a) Ravikumar et al. (1985); (b) Neurohr et al. (2015) and Castro et al. (2011); (c) Weyna et al. (2009); (d) Manoj et al. (2014); (e) Tumanova et al. (2014), Tilborg et al. (2013) and Yuan et al. (2001)

2NPX-NA prevents the formation of synthon B (seen in NPX-INA), due to the unfavourable distortion required for the groups in the correct orientation to interact (Ando et al., 2012). Consequently, synthon $\mathbf{E}$ is formed instead. Synthon $\mathbf{A}$ is present in most of the NPX-amino acid cocrystals, highlighting the preference for the formation of carboxylic acidcarboxylic acid dimers. The preparation of cocrystals between NPX and the third pyridine carboxamide isomer, picolinamide (PA, Scheme 1), has been suggested by Castro et al. (2011); however, single crystals were not available and so no X-ray structure was determined.

Solid-state NMR (SS-NMR) is sensitive to the local structure, and NMR crystallography studies have been employed extensively to characterize hydrogen bonding in a variety of cocrystals (Harris et al., 2009; Stevens et al., 2014; Vogt et al., 2009; Gobetto et al., 2005; Chierotti \& Gobetto, 2013; Brown, 2012), including cocrystals of NPX. For example, 2NPX-NA was investigated by two-dimensional $(2 \mathrm{D}){ }^{1} \mathrm{H}-{ }^{13} \mathrm{C}$ heteronuclear correlation (HETCOR) experiments that confirmed the hydrogen-bonding network was a relatively rare example of a single carboxyl group giving rise to two different intermolecular synthons in the same cocrystal, probably due to the 2:1 stoichiometry (Ando et al., 2012). Pure NPX and its sodium salt have also been studied by SS-NMR methods, with full chemical-shift assignment and ring-current effects investigated in 2013 (Carignani et al., 2013), while ${ }^{23} \mathrm{Na}$ SS-NMR experiments were also used to study NPX hydrates and solvates (Burgess et al., 2012). The ${ }^{13} \mathrm{C}$ and ${ }^{1} \mathrm{H}$ spectral assignments of NPX have been critically analysed recently using calculated NMR parameters with density functional theory (DFT), with three correlations from the paper by Ando et al. (2012) reassigned in the crowded region of the ${ }^{1} \mathrm{H}-{ }^{13} \mathrm{C}$ HETCOR spectra (Czernek, 2015). The tetrahydrate sodium salt of NPX has a 
complex disordered sodium and water network, which can be interpreted in terms of either stacking faults or multiple twinning following an NMR crystallography study utilizing SS-NMR, XRD and computational methods (Bond et al., 2013).

SS-NMR is well suited to the study of hydrogen-bonding networks in cocrystals (Maruyoshi et al., 2012; Tatton et al., 2013; Dudenko et al., 2013; Reddy et al., 2015), including locating protons in short hydrogen bonds. A combination of ${ }^{1} \mathrm{H}$ and ${ }^{15} \mathrm{~N}$ SS-NMR is commonly used to determine proton positions over $\mathrm{O}-\mathrm{H} \cdots \mathrm{O}$ and $\mathrm{O}-\mathrm{H} \cdots \mathrm{N}$ hydrogen bonds due to the sensitivity of the chemical shift to the local environment. For example, two sulfathiazole-oxalic acid complexes have been shown to be salts by multinuclear SS-NMR (Koike et al., 2014) and recently a furosemide-isonicotinamide complex was confirmed to be a cocrystal by comparison of ${ }^{15} \mathrm{~N}$ SS-NMR and DFT-calculated chemical shifts (Kerr et al., 2015). Another aspect of the study of proton position is the characterization of reversible proton migration over short strong hydrogen bonds, which is of fundamental interest but also potentially relevant to some types of functional materials (Ford et al., 2011; Frantsuzov et al., 2014).

We report here the growth of NPX-PA single crystals, the structure determination by single-crystal X-ray diffraction, the preparation of a pure polycrystalline sample of this cocrystal and the determination of its pharmaceutically-relevant properties. The details of the hydrogen-bonding network are investigated with NMR crystallography methods.

\section{Experimental}

\subsection{Synthesis and crystal growth}

NPX-PA was synthesized via a mechanochemical route. Equimolar $(0.5 \mathrm{mmol})$ amounts of $(S)$-NPX and PA were ground together using a mortar and pestle for $30 \mathrm{~min}$ with the gradual addition of a total of 6 drops of ethanol. A soft white powder was produced. The sample was reground for $30 \mathrm{~min}$ with the addition of a further 4 drops of ethanol in order to obtain the cocrystal as a single polycrystalline phase.

A small portion $(3 \mathrm{mg})$ of the polycrystalline material was refluxed in acetone at approximately $353 \mathrm{~K}$ for $20 \mathrm{~min}$. Solutions were left to evaporate in vials with pierced lids both at room temperature and in a fridge. Clear rectangular plate-like crystals appeared in both vials after $24 \mathrm{~h}$.

\subsection{Single-crystal X-ray diffraction}

Crystal data, data collection and structure refinement details are summarized in Table 2. Crystals that had crystallized at both temperatures (\$2.1) were screened. They were the same product and the crystals were of similar quality. $\mathrm{H}$ atoms not involved in hydrogen bonding were placed geometrically and treated using a riding model (Cooper et al., 2010). The six $\mathrm{H}$ atoms potentially involved in hydrogen bonding (H31, H201, H202, H291, H292 and H361) were located from difference Fourier maps, and their fractional coordinates and isotropic atomic displacement parameters
Table 2

Experimental details.

\begin{tabular}{|c|c|}
\hline \multicolumn{2}{|l|}{ Crystal data } \\
\hline Chemical formula & $\mathrm{C}_{14} \mathrm{H}_{14} \mathrm{O}_{3} \cdot \mathrm{C}_{6} \mathrm{H}_{6} \mathrm{~N}_{2} \mathrm{O}$ \\
\hline$M_{\mathrm{r}}$ & 352.39 \\
\hline Crystal system, space group & Monoclinic, $P 2_{1}$ \\
\hline Temperature / $\mathrm{K}$ & 120 \\
\hline$a, b, c / \AA$ & $5.3048(5), 31.891(3), 10.508(1)$ \\
\hline$\beta 1^{\circ}$ & $98.184(3)$ \\
\hline$V / \AA^{3}$ & $1759.6(3)$ \\
\hline Z & 4 \\
\hline Radiation type & Мо $K \alpha$ \\
\hline$\mu / \mathrm{mm}^{-1}$ & 0.09 \\
\hline Crystal size / mm & $0.12 \times 0.04 \times 0.02$ \\
\hline \multicolumn{2}{|l|}{ Data collection } \\
\hline Diffractometer & Bruker Venture D8 \\
\hline $\begin{array}{l}\text { No. of measured, independent and } \\
\text { observed }[I>2 \sigma(I)] \text { reflections }\end{array}$ & $19879,8939,5437$ \\
\hline$R_{\text {int }}$ & 0.045 \\
\hline$(\sin \theta / \lambda)_{\max } / \AA^{-1}$ & 0.717 \\
\hline \multicolumn{2}{|l|}{ Refinement } \\
\hline$R\left[F^{2}>2 \sigma\left(F^{2}\right)\right], w R\left(F^{2}\right), S$ & $0.058,0.082,0.94$ \\
\hline No. of reflections & 5437 \\
\hline No. of parameters & 493 \\
\hline No. of restraints & 1 \\
\hline $\mathrm{H}$-atom treatment & $\begin{array}{l}\mathrm{H} \text { atoms treated by a mixture of } \\
\text { independent and constrained } \\
\text { refinement }\end{array}$ \\
\hline$\Delta \rho_{\max }, \Delta \rho_{\min } / \mathrm{e} \AA^{-3}$ & $0.39,-0.32$ \\
\hline
\end{tabular}

Computer programs: APEX2 (Bruker, 2012), SIR92 (Altomare et al., 1993) and CRYSTALS (Betteridge et al., 2003).

were freely refined. The Flack (1983) parameter could not be determined reliably.

\subsection{Powder X-ray diffraction}

Powder X-ray diffraction (PXRD) data were collected on a Bruker D8 ADVANCE diffractometer $\left(\mathrm{Cu} K \alpha_{1,2}\right.$ radiation) and a LynxEye detector. Patterns were recorded in ranges between 4 and $50^{\circ}$ using a step size of $0.014^{\circ}$. Data analysis was carried out by the Rietveld method (Rietveld, 1969) using TOPAS-Academic software (Coelho et al., 2011).

\subsection{Solid-state nuclear magnetic resonance (SS-NMR)}

${ }^{13} \mathrm{C}$ cross-polarization (CP)/magic-angle spinning (MAS) measurements of pure NPX, a physical mix of NPX and PA, and the NPX-PA cocrystal were recorded on a Varian VNMRS 400 spectrometer using an $8 \mathrm{kHz}$ spinning rate, a recycle delay of $5 \mathrm{~s}$ and a contact time of $5.0 \mathrm{~ms}$. TPPM decoupling was applied during acquisition with a ${ }^{1} \mathrm{H}$ nutation rate of $74 \mathrm{kHz}$. Spectra were referenced to neat TMS by setting the high shift resonance of a replacement sample of adamantane to $38.5 \mathrm{ppm}$.

All other spectra were recorded on a Bruker Avance III HD spectrometer operating at a ${ }^{1} \mathrm{H}$ frequency of $499.6 \mathrm{MHz}$ and a ${ }^{13} \mathrm{C}$ frequency of $125.7 \mathrm{MHz}$. The ${ }^{1} \mathrm{H}-{ }^{13} \mathrm{C}$ FSLG-HETCOR experiment was carried out at $10 \mathrm{kHz}$ MAS with a $20 \mathrm{~s}$ recycle delay and a $1 \mathrm{~ms}$ contact time. $64 t_{1}$ increments were acquired with 48 transients per increment. ${ }^{13} \mathrm{C}$ spectra were referenced by setting the carbonyl resonance of a replacement sample of $\alpha$-glycine to $176.5 \mathrm{ppm}$. The ${ }^{1} \mathrm{H}$ experiment was carried out on 


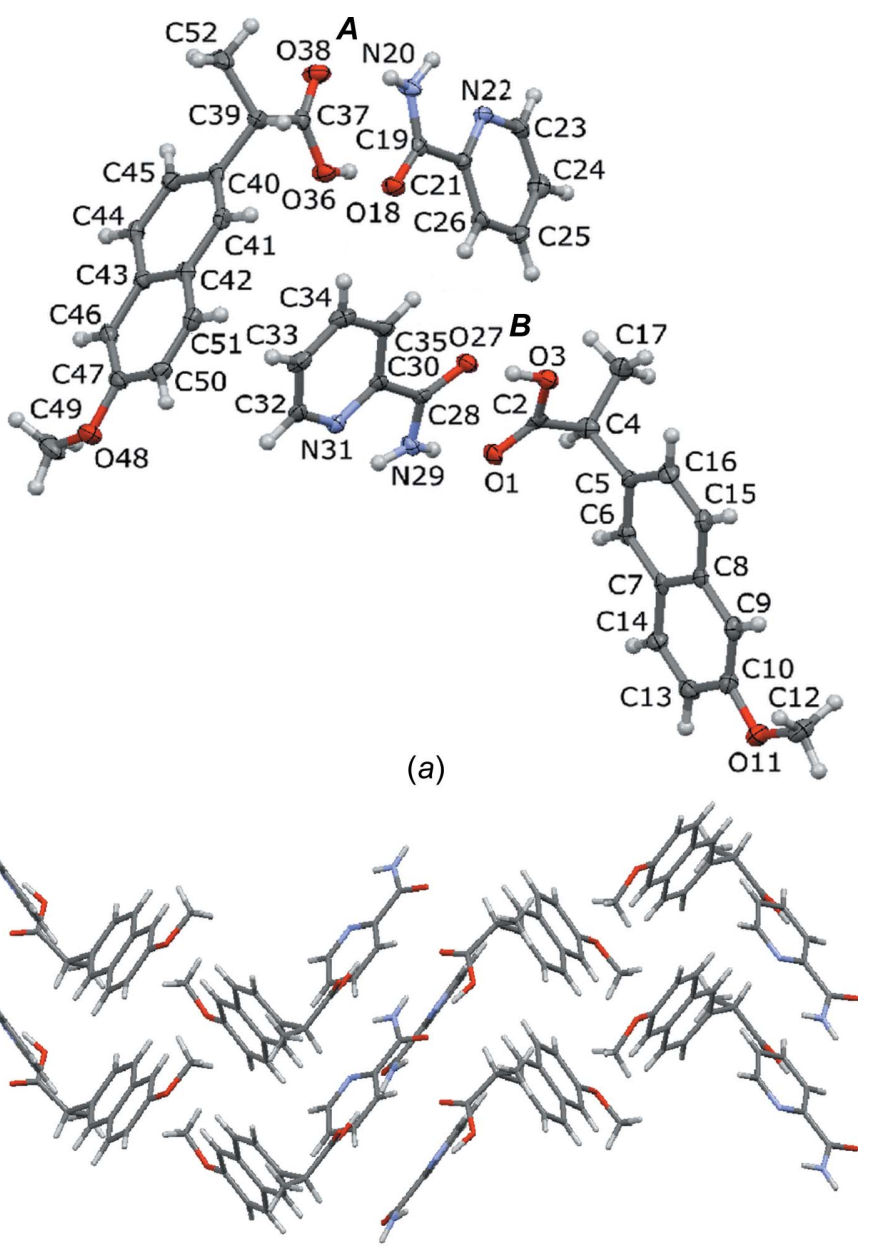

(b)

Figure 2

(a) The asymmetric unit of NPX-PA, with displacement ellipsoids shown at the $50 \%$ probability level and heavy atoms labelled. $\mathrm{H}$ atoms are shown with a fixed radius of $0.15 \AA$. (b) The crystal packing in NPX-PA, viewed along the $c$ axis.

a $1.3 \mathrm{~mm}$ probe (rotor outer diameter) at a spinning rate of $60 \mathrm{kHz}$ with a recycle delay of $20 \mathrm{~s}$. The ${ }^{1} \mathrm{H}$ spectrum was referenced by setting the resonance of a replacement sample of adamantane to $1.9 \mathrm{ppm}$. The ${ }^{1} \mathrm{H}$ dimensions of the HETCOR spectra were rescaled using the default FSLG scaling factor and then referenced using resolved peaks from the ${ }^{1} \mathrm{H}$ MAS spectrum.

\subsection{Computational methods}

First principles calculations were carried out using the GIPAW method implemented in CASTEP (Clark et al., 2005). All calculations were performed using the PBE functional (Perdew et al., 1996) and on-the-fly-generated ultrasoft pseudopotentials, with a cut-off energy of $700 \mathrm{eV}$. Geometry optimization of all 184 atom positions was carried out with the centre of mass and unit-cell parameters fixed, with integrals taken over the Brillouin zone using a Monkhorst-Pack grid with a maximum $k$-point sample spacing of $0.1 \AA^{-1}$, corresponding to a single $k$-point. As discussed below, alternative hydrogen-bonding models were produced by moving the $\mathrm{H}$ atoms along the vector of the hydrogen bonds in 16 equal increments by editing the Cartesian coordinates of the geometry-optimized structure. The energy was calculated at each position using a single-point calculation, with a cut-off energy of $700 \mathrm{eV}$. Geometry optimization including dispersion correction did not significantly change the $\mathrm{H}$-atom positions or predicted shielding values.

The NMR parameters were calculated using a $k$-point sample spacing of $0.05 \AA^{-1}$ corresponding to $4 k$-points and an offset of $\left(\frac{1}{4}, \frac{1}{4}, \frac{1}{4}\right)$ to avoid sampling the $\Gamma$ point. The resulting shielding values were converted to chemical shifts and referenced using $\delta_{\text {iso }}=\sigma_{\text {ref }}-\sigma_{\text {iso }}$, where $\sigma_{\text {iso }}$ is the CASTEPcalculated shielding value and $\sigma_{\text {ref }}$ was calculated to equate the average calculated shift and average experimental shift (Harris et al., 2007). The $\sigma_{\text {ref }}$ values are given in Table S3 in the Supporting information, along with the r.m.s. deviations (RMSDs) of the calculated ${ }^{1} \mathrm{H}$ and ${ }^{13} \mathrm{C}$ NMR parameters compared for the different hydrogen-bonding models.

\subsection{Thermal analysis}

Differential scanning calorimetry (DSC) measurements were carried out using a TA DSC Q1000 instrument equipped with a nitrogen purge gas, using $4-5 \mathrm{mg}$ of sample. The heating rate was $10 \mathrm{~K} \mathrm{~min}^{-1}$.

\subsection{Property measurements}

To compare the solubility of NPX and the NPX-PA cocrystal, intrinsic dissolution rate (IDR) and equilibrium solubility studies in $\mathrm{pH} 7$ phosphate buffer medium were performed. The equilibrium solubility of NPX was measured $\left(4.32 \mathrm{~g}^{-1}\right)$, but that of the NPX-PA cocrystal could not be determined since the material dissociated to its starting components (as observed by PXRD). The IDR experiments were carried out on a USP-certified Electrolab TDT-08L dissolution tester type II (paddle) (Mumbai, India) for $6 \mathrm{~h}$ (Higuchi \& Connors, 1965). Prior to IDR determination, standard curves for both NPX and NPX-NA were obtained spectrophotometrically.

\section{Results and discussion}

\subsection{Single-crystal X-ray diffraction and physicochemical properties}

NPX-PA crystallizes in the space group $P 2_{1}$ with four molecules in the asymmetric unit [two active pharmaceutical ingredient (API) and two conformer molecules]. The molecules form heterodimers via synthon $\mathbf{E}$ (Fig. 1). The presence of four molecules in the asymmetric unit yields two inequivalent $\mathbf{E}$ heterodimers, arranged in an edge-to-face herringbone pattern along the crystallographic $c$ axis. The dimers interact with each other via synthon $\mathbf{C}$, with an $\mathrm{O} \cdots \mathrm{N}$ distance of 3.022 (4) $\AA$. The synthons and their packing can be seen in Fig. 2 and details of the hydrogen-bonding distances in NPXPA are summarized in Table 3. These distances fall within the range observed in other structures containing the synthon $\mathbf{E}$ 
Table 3

The geometry $\left(\AA,^{\circ}\right)$ of the hydrogen bonds in the NPX-PA single-crystal XRD structure.

\begin{tabular}{|c|c|c|c|c|c|}
\hline Dimer & Hydrogen bond & $D-\mathrm{H}$ & $\mathrm{H} \cdots A$ & $D \cdots A$ & $D-\mathrm{H} \cdots A$ \\
\hline \multirow[t]{2}{*}{4} & $\mathrm{O} 36$ & $0.85(4)$ & $1.74(4)$ & $2.572(5)$ & $166(4)$ \\
\hline & $\mathrm{N} 20-\mathrm{H} 202 \cdots \mathrm{O} 38$ & $0.85(4)$ & $2.15(4)$ & $2.965(5)$ & $158(4)$ \\
\hline \multirow[t]{2}{*}{$B$} & $\mathrm{O} 3-\mathrm{H} 31 \cdots \mathrm{O} 27^{\mathrm{i}}$ & $0.97(6)$ & $1.62(6)$ & $2.579(5)$ & $169(6)$ \\
\hline & $\mathrm{N} 29-\mathrm{H} 291 \cdots \mathrm{O} 1^{\mathrm{ii}}$ & $0.81(4)$ & $2.08(4)$ & $2.890(5)$ & $175(4)$ \\
\hline
\end{tabular}

Symmetry codes: (i) $x-1, y, z$; (ii) $x+1, y, z$.

dimer (see Fig. S1 in the Supporting information). The structural model obtained from single-crystal diffraction was used to fit the PXRD data obtained on the bulk sample. The Rietveld fit obtained is shown in Fig. S3 (see Supporting information) and no peaks are unaccounted for, implying that the polycrystalline material prepared by mechanochemistry is a single-phase product.

The structure obtained is consistent with the trends seen in previously determined NPX cocrystal structures. In particular, the heterodimer formation between carboxylic acid and amide groups, linked by a further single interaction is reminiscent of the synthon formation in 2NPX-NA and NPX-INA. However, synthon D is not observed in NPX-PA, despite being present in 2NPX-NA and NPX-INA, and alternatively synthon $\mathbf{E}$ is formed. This demonstrates the role of basicity in cocrystal formation with NPX. Among the three pyridinecarboxamide coformers, NA and INA are more basic $\left(\mathrm{p} K_{a}\right.$ values of 3.63 and 3.45 ), so the acid-pyridine synthon $\mathbf{D}$ is observed. Additionally, in 2NPX-NA, the other NPX molecule is associated with NA via the acid-amide synthon $\mathbf{E}$. However, PA exhibits the ortho effect and is less basic [p $K_{\mathrm{a}}$ value of 1.17 (Mihala, 2016; ChemAxon, 2016)], so the PA carboxamide group interacts with NPX via synthon E (acidamide) rather than synthon $\mathbf{D}$.

The DSC trace of NPX-PA shows a single endothermic peak at $366 \mathrm{~K}$, which represents the melting of a single solid phase (see Fig. S4 in the Supporting information). This is in keeping with the endothermic peak observed at $364 \mathrm{~K}$ by Castro et al. (2011), and is lower than that of both starting components (NPX $425 \mathrm{~K}$ and PA $375 \mathrm{~K}$ ). The intrinsic dissolution rates of NPX and the NPX-PA cocrystal were found to

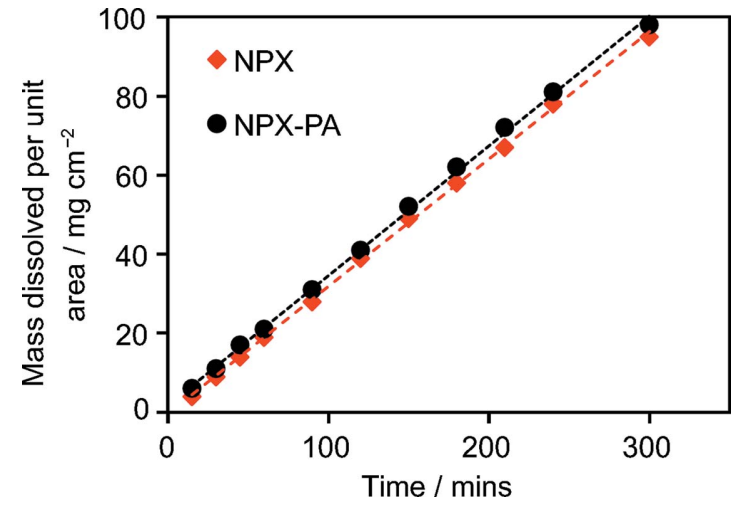

Figure 3

Dissolution curves for pure NPX (black squares) and the NPX-PA cocrystal (red circles) measured over a $6 \mathrm{~h}$ period. be 1.26 and $1.39 \mathrm{mg} \mathrm{cm}^{-2} \mathrm{~min}^{-1}$, respectively, i.e. the NPX-PA cocrystal dissolves at essentially the same rate as commercial NPX (Fig. 3). The identity of the undissolved materials at the end of the dissolution experiment was confirmed to be unchanged by PXRD.

One question that arises from the structure determination concerns the $\mathrm{O}-\mathrm{H} \cdots \mathrm{O}$ hydrogen bonds in the two crystallographically unique synthon $\mathbf{E}$ dimers. While the donoracceptor $(D-A)$ distances are essentially the same (see Table 3$)$, the situation with the donor-hydrogen $(D-\mathrm{H})$ bond lengths is less clear-cut given the larger standard uncertainties of these parameters and systematic issues with locating $\mathrm{H}$ atom positions using X-ray scattering. In particular, the $D-\mathrm{H}$ distances might suggest that the crystallographically unique $\mathrm{COOH}-\mathrm{CONH}$ dimers are significantly different, but the large standard errors of the $\mathrm{H}$-atom positions preclude any definitive conclusions. Given the strong sensitivity of NMR shifts to the local structure, it is expected that NMR spectra would help to confirm the location of the $\mathrm{H}$ atoms within the hydrogen bonds.

\subsection{NMR crystallography}

Comparison of the ${ }^{13} \mathrm{C}$ spectra of the pure components with that of the grinding product confirms the formation of a cocrystal (Fig. 4). The physical mixture and pure NPX show identical spectra, consistent with a lack of interaction between components. Peaks from PA are not observed because the pure PA coformer has a long ${ }^{1} \mathrm{H} T_{1}$ relaxation time compared to the recycle delay of $5 \mathrm{~s}$. The spectrum of the NPX-PA cocrystal is distinctly different. Firstly, some of the resonances arising from NPX have shifted relative to the pure NPX spectrum, e.g. the $\mathrm{C} 9 / \mathrm{C} 46$ peak. The deshielding observed for the NPX COOH sites, i.e. C2 and C37, is consistent with the formation of hydrogen bonds (Asakawa et al., 1992). Secondly,

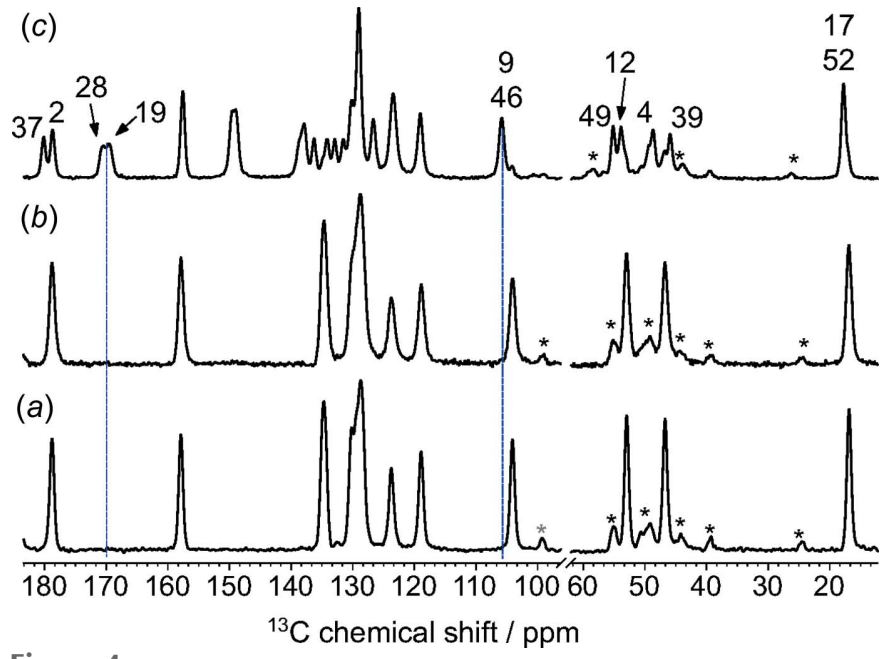

Figure 4

${ }^{13} \mathrm{C} \mathrm{CP} / \mathrm{MAS}$ spectra of $(a)$ pure NPX, $(b)$ a physical mixture of NPX and $\mathrm{PA}$, and $(c)$ the NPX-PA cocrystal acquired at a ${ }^{13} \mathrm{C}$ frequency of 100.56 MHz. Peaks marked with an asterix are spinning sidebands and the dashed blue lines are guides for the eye to show new or shifted peaks in the cocrystal. 


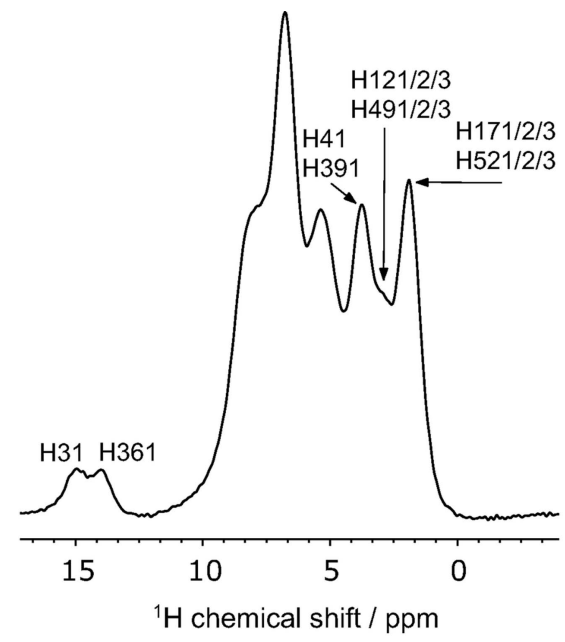

(a)

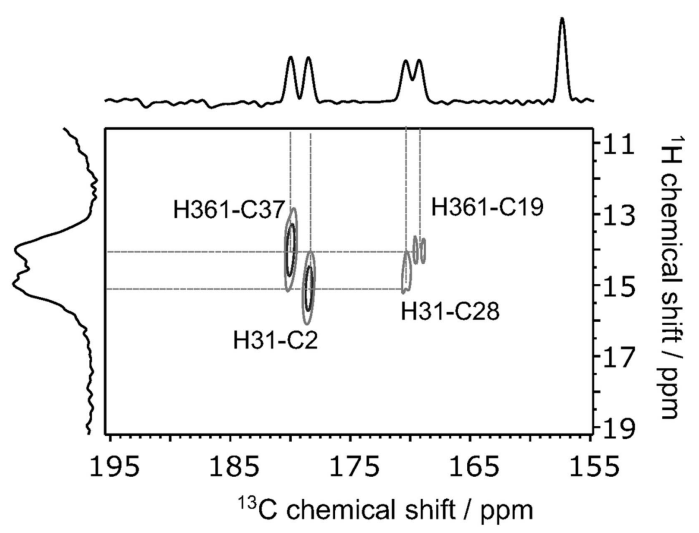

(b)

Figure 5

(a) The ${ }^{1} \mathrm{H}$ NMR spectrum of NPX-PA at $60 \mathrm{kHz}$ MAS. Atom labelling is given for some sites such that the $\mathrm{H}$-atom label is $\mathrm{H} X 1$, where $X$ is the label of the directly bonded heavy atom, for example, the $\mathrm{H}$ atom on $\mathrm{O} 36$ is $\mathrm{H} 361$. (b) A section of the ${ }^{1} \mathrm{H}-{ }^{13} \mathrm{C}$ HETCOR spectrum of NPX-PA, with the hydrogen-bonded proton peaks and the NPX carboxyl carbon peaks labelled.

signals are now observed from PA carbon sites as a result of the intimate association of PA and NPX, which shortens the ${ }^{1} \mathrm{H} T_{1}$ relaxation time of the PA resonances. The doubling of most signals is consistent with the presence of two crystallographically non-equivalent molecules of NPX and PA in the asymmetric unit determined from single-crystal X-ray diffraction. Key peaks are assigned in Fig. 5, and the full assignment is given in Fig. S5 and Table S3 in the Supporting information. The spectral assignments were aided by a ${ }^{13} \mathrm{C}$ spectrum with the nonquaternary carbon peaks suppressed (Fig. S4 in the Supporting information) and $2 \mathrm{D}{ }^{1} \mathrm{H}-{ }^{13} \mathrm{C}$ heteronuclear correlation (HETCOR) experiments (Figs. S5 and S6 in the Supporting information), as well as CASTEPcalculated shieldings (Figs. S8 and S9 in the Supporting information), discussed below. A direct-excitation ${ }^{13} \mathrm{C}$ experiment (not shown) with a short recycle delay of $0.5 \mathrm{~s}$ showed that the only obviously dynamic sites are the methyl groups.

The ${ }^{1} \mathrm{H}$ spectrum of NPX-PA acquired with fast MAS of $60 \mathrm{kHz}$ (Fig. 5a), shows comparable resolution with that of the 2NPX-NA spectrum presented by Ando et al. (2012). It is likely that the chemical shifts of some of the protons are affected by intermolecular ring-current effects due to the edge-to-face herringbone structure of NPX-PA, which is similar to that of pure NPX (Carignani et al., 2013). Whilst the broad linewidths of ${ }^{1} \mathrm{H}$ SS-NMR can hinder the ability of SSNMR to distinguish between protons in hydrogen bonds of the same type, there are many cocrystals/salts for which it is possible (Vogt et al., 2009; Gobetto et al., 2005; Sardo et al., 2015; Harris et al., 2010), including this case of NPX-PA. Not all ${ }^{1} \mathrm{H}$ peaks could be assigned, but the peaks of the two protons involved in the synthon $\mathbf{E}$ dimers, i.e. H31 and H361, can be distinguished. Variable recycle delay experiments showed that the $T_{1}$ relaxation of the hydrogen-bonded protons was significantly slower than that of other $\mathrm{H}$ atoms, and so a $20 \mathrm{~s}$ recycle delay was used to acquire the spectra shown in Fig. 6.
Atoms $\mathrm{H} 31$ and $\mathrm{H} 361$ can be assigned unambiguously due to the observation of strong correlations to the NPX carbonyl $\mathrm{C}$ atoms (C2/C37) in a HETCOR spectrum acquired with a $1 \mathrm{~ms}$ contact time (Fig. 6b). Additionally, weak correlations are observed to $\mathrm{C} 19 / \mathrm{C} 28$, the PA amide $\mathrm{C}$ atoms involved in the dimers of synthon $\mathbf{E}(\mathrm{H} 31 \cdots \mathrm{C} 28=2.41 \AA$ and $\mathrm{H} 361 \cdots \mathrm{C} 19=2.39 \AA)$. Similarly, a ${ }^{1} \mathrm{H}-{ }^{1} \mathrm{H}$ double quantum/ single quantum spectrum (DQ/SQ) (see Fig. S9 in the Supporting information), also shows direct evidence of the synthon $\mathbf{E}$ dimers by means of correlations between $\mathrm{H} 31 / \mathrm{H} 361$ and the amide protons $\mathrm{H} 291 / \mathrm{H} 202$. The HETCOR spectra also help to confirm the positioning of the $\mathrm{H}$ atoms; the $\mathrm{C} 19$ / C28 correlations would be expected to be more intense than the $\mathrm{C} 2 / \mathrm{C} 37$ correlations if the protons were nearer the amide $\mathrm{C}$ atoms in the $\mathrm{N}-\mathrm{H} \cdots \mathrm{O}$ hydrogen bond. The observed correlation intensities, therefore, support the assignment of hydrogen-bond donors and acceptors by single-crystal XRD.

The positions of atoms $\mathrm{H} 31$ and $\mathrm{H} 361$ within the hydrogen bonds is further investigated by comparing the experimental NMR data to predicted shift values. The structure obtained from XRD was first geometry optimized using DFT. Optimization of all the atom positions results in a structure with a small total heavy-atom RMSD between the optimized and original structures of $0.09 \AA$. As would be expected, however, the positions of $\mathrm{H}$ atoms refined from X-ray scattering are significantly adjusted, by $\sim 0.2 \AA$, on optimization. This is within the usual range observed when comparing hydrogenbond distances from X-ray scattering and neutron scattering experiments (Wells, 1984). As shown in Table S1 (see Supporting information), the hydrogen bonds become more symmetric and the difference between the two $\mathrm{O}-\mathrm{H} \cdots \mathrm{O}$ hydrogen bonds largely disappears, which is consistent with the small difference ( $\sim 1$ p.p.m.) in the ${ }^{1} \mathrm{H}$ shifts for atoms $\mathrm{H} 31$ and $\mathrm{H} 361$.

Two hydrogen-bonding models can be proposed as alternatives to the XRD refinement, see Fig. S9(i) in the 


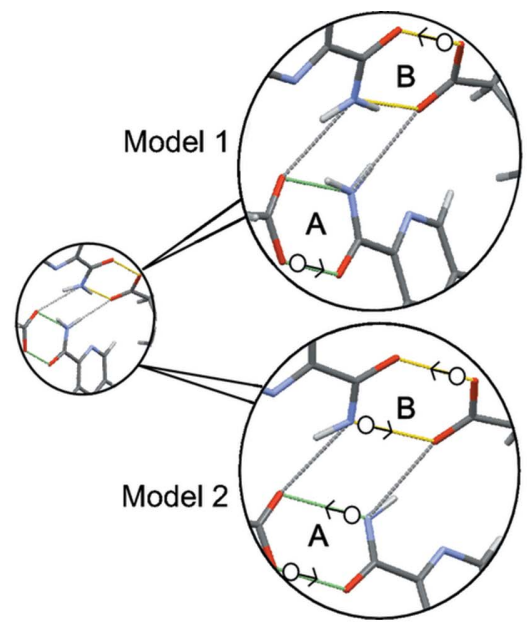

(a)

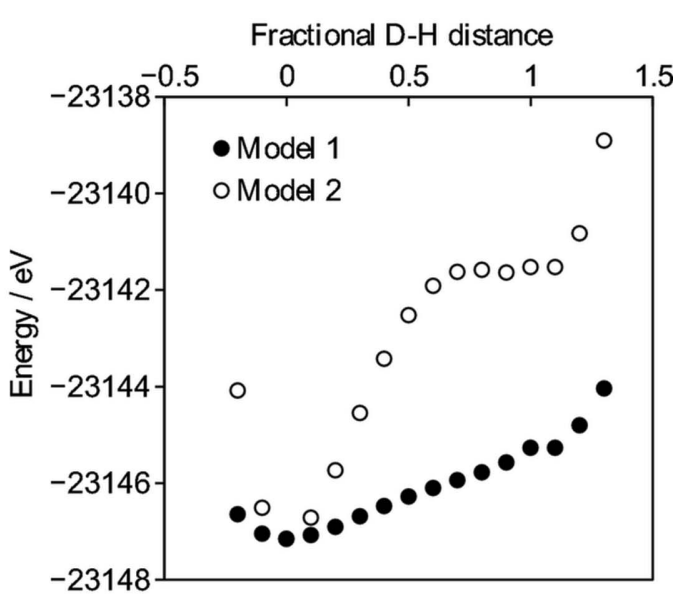

(b)

Figure 6

(a) Schematic showing the $\mathrm{H}$ atoms that were moved in tandem along the vector between the $\mathrm{H}$ atom and its acceptor atom to form Model 1 and Model 2. The white circles indicate the initial position of the $\mathrm{H}$ atoms from the XRD structure and the arrows indicate the direction of movement. $(b)$ The energy of NPX-PA as a function of H-atom position. A fractional distance of 0 corresponds to the DFT-optimized XRD position, while a distance of 1 corresponds to the $\mathrm{H}$ atom being at the equivalent position on the other side of the hydrogen bond. Negative fractional distances correspond to movement towards the donor atom.

Supporting information. In Model 1, only the $\mathrm{H}$ atoms in the short $\mathrm{O}-\mathrm{H} \cdots \mathrm{O}$ hydrogen bonds were moved, and in Model 2 the amide protons in PA were also moved along the $\mathrm{N}-\mathrm{H} \cdots \mathrm{O}$ hydrogen bond. Specifically, atom $\mathrm{H} 361$ was moved from O36 to $\mathrm{O} 18$ and atom $\mathrm{H} 31$ was moved from $\mathrm{O} 3$ to $\mathrm{O} 27$ in dimers $A$ and $B$, respectively, in Model 1. In Model 2, atom $\mathrm{H} 202$ was also moved from $\mathrm{N} 20$ to $\mathrm{O} 38$ and atom $\mathrm{H} 291$ was moved from N29 to $\mathrm{O} 1$ in dimers $A$ and $B$, respectively. Note that there is a net proton transfer in Model 1, resulting in a salt form, while Model 2 is an alternative cocrystal (see Fig. S2 in the Supporting information). The calculated potential energy as a function of $\mathrm{H}$-atom position for these models is shown in Fig. 6(b). There is a single energy minimum in both cases, corresponding to the structure determined from XRD. It is important to note that DFT calculations have some systematic weaknesses in describing hydrogen bonding, e.g. in a furosemide-isonicotinamide cocrystal, the energetic minimum in a short strong $\mathrm{O}-\mathrm{H} \cdots \mathrm{N}$ hydrogen bond was predicted incorrectly, as shown by experimental ${ }^{15} \mathrm{~N}$ NMR and XRD data (Kerr et al., 2015). Moreover, the DFT calculations effectively involve $0 \mathrm{~K}$ structures, while experimental SC-XRD and NMR were carried out at $120 \mathrm{~K}$ and ambient temperature, respectively. However, the potential curves in Fig. 6(b) each show a single steep minimum, so alternative positions for the $\mathrm{H}$ atoms are implausible and temperature-dependent proton transfer over the hydrogen bonds is highly unlikely. This contrasts with a previously reported system, namely pyridine3,5-dicarboxylic acid, where an NMR crystallography study revealed the presence of quantum tunnelling of a proton across a hydrogen bond with a shallow double minimum in the potential energy surface (Frantsuzov et al., 2014). In this context, it is important to note that only the NMR parameters calculated from the geometry-optimized XRD structure are compatible with the experimental data, as discussed in Figs. S8 and S9 in the Supporting information. In particular, the
RMSDs between experimental and calculated ${ }^{13} \mathrm{C}$ shifts are over 2 p.p.m. (Table S2 in the Supporting information) if the $\mathrm{H}$ atoms are moved to the other side of the hydrogen bond, according to either Model 1 or Model 2, which is inconsistent with valid structures for molecular organics (Bonhomme et al., 2012; Widdifield et al., 2016).

\section{Conclusions}

The crystal structure of NPX-PA was refined from singlecrystal XRD and was found to contain two crystallographically unique NPX and PA molecules that form two carboxylic acid-carboxamide dimers between NPX and PA. The intrinsic dissolution rate of NPX-PA was found to be the same as that of commercial NPX and the apparent solubility could not be measured because the cocrystal dissociated into the pure starting components. This contrasts with previously described cocrystals of NPX, which have improved dissolution rates compared to pure NPX and low hygroscopicity.

DFT geometry optimization was used to refine the positions of the $\mathrm{H}$ atoms, resulting in an excellent agreement with experimental evidence from ${ }^{13} \mathrm{C}$ and ${ }^{1} \mathrm{H}$ solid-state NMR. The calculated potential energies as a function of $\mathrm{H}$-atom position validate the overall positioning determined by XRD, confirming that NPX-PA is a cocrystal and not a salt. The hydrogen-bonded $\mathrm{H}$ atoms in the two crystallographically unique dimers could be distinguished experimentally, despite the two environments being very similar in the geometryoptimized structures, demonstrating the sensitivity of NMR spectra to $\mathrm{H}$-atom position.

\section{Acknowledgements}

HEK is supported by an EPSRC Doctoral Training Grant studentship. KS thanks UGC for a fellowship and DST 
(IRPHA and PURSE) and UGC (UPE grant) are thanked for providing instrumentation and infrastructure facilities at the University of Hyderabad. IRE thanks ANSTO for a visiting researcher post. The solid-state NMR spectra presented in Fig. 5 were obtained at the EPSRC UK National Solid-State NMR Service at Durham. We thank Professor Ashwini Nangia, University of Hyderabad, for his suggestions on a draft of this manuscript. The original research data can be accessed through doi:10.15128/r15x21tf407.

\section{References}

Altomare, A., Cascarano, G., Giacovazzo, C. \& Guagliardi, A. (1993). J. Appl. Cryst. 26, 343-350.

Ando, S., Kikuchi, J., Fujimura, Y., Ida, Y., Higashi, K., Moribe, K. \& Yamamoto, K. (2012). J. Pharm. Sci. 101, 3214-3221.

Asakawa, N., Kuroki, S., Kurosu, H., Ando, I., Shoji, A. \& Ozaki, T. (1992). J. Am. Chem. Soc. 114, 3261-3265.

Betteridge, P. W., Carruthers, J. R., Cooper, R. I., Prout, K. \& Watkin, D. J. (2003). J. Appl. Cryst. 36, 1487.

Bond, A. D., Cornett, C., Larsen, F. H., Qu, H., Raijada, D. \& Rantanen, J. (2013). Cryst. Growth Des. 13, 3665-3671.

Bonhomme, C., Gervais, C., Babonneau, F., Coelho, C., Pourpoint, F., Azais, T., Ashbrook, S. E., Griffin, J. M., Yates, J. R., Mauri, F. \& Pickard, C. J. (2012). Chem. Rev. 112, 5733-5779.

Brown, S. P. (2012). Solid State Nucl. Magn. Reson. 41, 1-27.

Bruker (2012). APEX2. Bruker AXS Inc., Madison, Wisconsin, USA.

Burgess, K. M., Perras, F. A., Lebrun, A., Messner-Henning, E., Korobkov, I. \& Bryce, D. L. (2012). J. Pharm. Sci. 101, 2930-2940.

Buschmann, H. H. D., Solà, C. L., Benet, B. J. \& Ceron, B. J. C. (2009). Eur. Patent No. EP 2123626 A1.

Buschmann, H. H., Solà, C. L., Ceron, B. J. C. \& Benet, B. J. (2010). Eur. Patent No. EP2177215 A1.

Carignani, E., Borsacchi, S., Bradley, J. P., Brown, S. P. \& Geppi, M. (2013). J. Phys. Chem. C, 117, 17731-17740.

Castro, R. A. E., Ribeiro, J. D. B., Maria, T. M. R., Silva, M. R., YusteVivas, C., Canotilho, J. \& Eusebio, M. E. S. (2011). Cryst. Growth Des. 11, 5396-5404.

ChemAxon (2016). Marvin. http://www.chemaxon.com.

Chierotti, M. R. \& Gobetto, R. (2013). CrystEngComm, 15, 8599 8612.

Clark, S. J., Segall, M. D., Pickard, C. J., Hasnip, P. J., Probert, M. J., Refson, K. \& Payne, M. C. (2005). Z. Kristallogr. 220, 567-570.

Coelho, A. A., Evans, J. S. O., Evans, I. R., Kern, A. \& Parsons, S. (2011). Powder Diffr. 26, S22.

Cooper, R. I., Thompson, A. L. \& Watkin, D. J. (2010). J. Appl. Cryst. 43, 1100-1107.

Czernek, J. (2015). Chem. Phys. Lett. 619, 230-235.

Desiraju, G. R. (1995). Angew. Chem. 34, 2311-2327.

Dudenko, D. V., Yates, J. R., Harris, K. D. M. \& Brown, S. P. (2013). CrystEngComm, 15, 8797-8807.

Flack, H. D. (1983). Acta Cryst. A39, 876-881.

Ford, S. J., Delamore, O. J., Evans, J. S., McIntyre, G. J., Johnson, M. R. \& Radosavljevic Evans, I. (2011). Chem. Eur. J. 17, 14942-14951.

Frantsuzov, I., Ford, S. J., Evans, I. R., Horsewill, A. J., Trommsdorff, H. P. \& Johnson, M. R. (2014). Phys. Rev. Lett. 113, 18301-18305.
Gobetto, R., Nervi, C., Chierotti, M. R., Braga, D., Maini, L., Grepioni, F., Harris, R. K. \& Hodgkinson, P. (2005). Chemistry, 11, 7461-7471.

Harris, R. K., Hodgkinson, P., Pickard, C. J., Yates, J. R. \& Zorin, V. (2007). Magn. Reson. Chem. 45 (Suppl. 1), S174-S186.

Harris, R. K., Hodgkinson, P., Zorin, V., Dumez, J. N., ElenaHerrmann, B., Emsley, L., Salager, E. \& Stein, R. S. (2010). Magn. Reson. Chem. 48 (Suppl. 1), S103-S112.

Harris, R. K., Wasylishen, R. E. \& Duer, M. J. (2009). In NMR Crystallography. West Sussex, UK: John Wiley \& Sons Ltd.

Higuchi, T. \& Connors, K. A. (1965). Adv. Anal. Chem. Instrum. 4, 117-212.

Kerr, H. E., Softley, L. K., Suresh, K., Nangia, A., Hodgkinson, P. \& Evans, I. R. (2015). CrystEngComm, 17, 6707-6715.

Koike, R., Higashi, K., Liu, N., Limwikrant, W., Yamamoto, K. \& Moribe, K. (2014). Cryst. Growth Des. 14, 4510-4518.

Manoj, K., Tamura, R., Takahashi, H. \& Tsue, H. (2014). CrystEngComm, 16, 5811-5819.

Maruyoshi, K., Iuga, D., Antzutkin, O. N., Alhalaweh, A., Velaga, S. P. \& Brown, S. P. (2012). Chem. Commun. 48, 10844-10846.

Mihala, N. (2016). $p K_{a}$ calculator in Marvin (Version 5.10.1). http:// www.chemaxon.com.

Neurohr, C., Marchivie, M., Lecomte, S., Cartigny, Y., Couvrat, N., Sanselme, M. \& Subra-Paternault, P. (2015). Cryst. Growth Des. 15, 4616-4626.

Perdew, J. P., Burke, K. \& Ernzerhof, M. (1996). Phys. Rev. Lett. 77, 3865-3868.

Ravikumar, K., Rajan, S. S., Pattabhi, V. \& Gabe, E. J. (1985). Acta Cryst. C41, 280-282.

Reddy, G. N., Cook, D. S., Iuga, D., Walton, R. I., Marsh, A. \& Brown, S. P. (2015). Solid State Nucl. Magn. Reson. 65, 41-48.

Rietveld, H. M. (1969). J. Appl. Cryst. 2, 65-71.

Sardo, M., Santos, S. M., Babaryk, A. A., Lopez, C., Alkorta, I., Elguero, J., Claramunt, R. M. \& Mafra, L. (2015). Solid State Nucl. Magn. Reson. 65, 49-63.

Stevens, J. S., Byard, S. J., Seaton, C. C., Sadiq, G., Davey, R. J. \& Schroeder, S. L. (2014). Phys. Chem. Chem. Phys. 16, 1150-1160.

Takagi, T., Ramachandran, C., Bermejo, M., Yamashita, S., Yu, L. X. \& Amidon, G. L. (2006). Mol. Pharm. 3, 631-643.

Tatton, A. S., Pham, T. N., Vogt, F. G., Iuga, D., Edwards, A. J. \& Brown, S. P. (2013). Mol. Pharm. 10, 999-1007.

Tilborg, A., Springuel, G., Norberg, B., Wouters, J. \& Leyssens, T. (2013). CrystEngComm, 15, 3341-3350.

Tumanova, N., Tumanov, N., Robeyns, K., Filinchuk, Y., Wouters, J. \& Leyssens, T. (2014). CrystEngComm, 16, 8185-8196.

Vogt, F. G., Clawson, J. S., Strohmeier, M., Edwards, A. J., Pham, T. N. \& Watson, S. A. (2009). Cryst. Growth Des. 9, 921-937.

Wells, A. F. (1984). In Structural Inorganic Chemistry, 5th ed. Oxford University Press.

Weyna, D. R., Shattock, T., Vishweshwar, P. \& Zaworotko, M. J. (2009). Cryst. Growth Des. 9, 1106-1123.

Widdifield, C. M., Robson, H. \& Hodgkinson, P. (2016). Chem. Commun. 52, 6685-6688.

Wishart, D. S., Knox, C., Guo, A. C., Shrivastava, S., Hassanali, M., Stothard, P., Chang, Z. \& Woolsey, J. (2006). Nucleic Acids Res. 34, D668-D672.

Yuan, X., Li, J., Tian, Y., Lee, G.-H., Peng, X.-M., Zhu, R. \& You, X. (2001). Tetrahedron Asymmetry, 12, 3015-3018. 


\section{supporting information}

Acta Cryst. (2017). C73, 168-175 [https://doi.org/10.1107/S2053229616011980]

\section{Structure and physicochemical characterization of a naproxen-picolinamide cocrystal}

\section{Hannah E. Kerr, Lorna K. Softley, Kuthuru Suresh, Paul Hodgkinson and Ivana Radosavljevic Evans}

\section{Computing details}

Data collection: APEX2 (Bruker, 2012); cell refinement: APEX2 (Bruker, 2012); data reduction: APEX2 (Bruker, 2012); program(s) used to solve structure: SIR92 (Altomare et al., 1993); program(s) used to refine structure: CRYSTALS (Betteridge et al., 2003); molecular graphics: CRYSTALS (Betteridge et al., 2003); software used to prepare material for publication: CRYSTALS (Betteridge et al., 2003).

(S)-2-(6-Methoxynaphthalen-2-yl) propanoic acid-pyridine-2-carboxamide (1/1)

Crystal data

$$
\begin{aligned}
& \mathrm{C}_{14} \mathrm{H}_{14} \mathrm{O}_{3} \cdot \mathrm{C}_{6} \mathrm{H}_{6} \mathrm{~N}_{2} \mathrm{O} \\
& M_{r}=352.39 \\
& \text { Monoclinic, } P 2_{1} \\
& a=5.3048(5) \AA \\
& b=31.891(3) \AA \\
& c=10.508(1) \AA \\
& \beta=98.184(3)^{\circ} \\
& V=1759.6(3) \AA^{3} \\
& Z=4
\end{aligned}
$$

\section{Data collection}

Unknown diffractometer

Graphite monochromator $\omega / 2 \theta$ scans 19879 measured reflections 8939 independent reflections

\section{Refinement}

Refinement on $F^{2}$

Least-squares matrix: full

$R\left[F^{2}>2 \sigma\left(F^{2}\right)\right]=0.058$

$w R\left(F^{2}\right)=0.082$

$S=0.94$

5437 reflections

493 parameters

1 restraint

Primary atom site location: other

Hydrogen site location: difference Fourier map

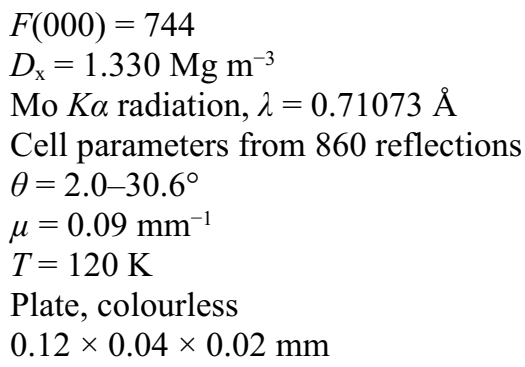

$\mathrm{H}$ atoms treated by a mixture of independent and constrained refinement 
Method, Chebychev polynomial, (Watkin, 1994;

Prince, 1982) $[$ weight $]=1.0 /\left[\mathrm{A}_{0} * \mathrm{~T}_{0}(\mathrm{x})+\right.$

$\left.\left.\mathrm{A}_{1} * \mathrm{~T}_{1}(\mathrm{x}) \cdots+\mathrm{A}_{\mathrm{n}-1}\right] * \mathrm{~T}_{\mathrm{n}-1}(\mathrm{x})\right]$

where $\mathrm{A}_{\mathrm{i}}$ are the Chebychev coefficients listed

below and $\mathrm{x}=F / F \max$ Method $=$ Robust

Weighting (Prince, 1982) W $=$ [weight ${ }^{*}$

$\left[1-\left(\operatorname{delta} F / 6^{*} \text { sigma } F\right)^{2}\right]^{2} \mathrm{~A}_{\mathrm{i}}$ are: 11.318 .812 .2

5.421 .50

Prince, E. (1982). In Mathematical Techniques in Crystallography and Materials Science. New York: Springer-Verlag.

Watkin, D. (1994). Acta Cryst. A50, 411-437.

$(\Delta / \sigma)_{\max }=0.0003004$

$\Delta \rho_{\max }=0.39{\mathrm{e} \AA^{-3}}^{-3}$

$\Delta \rho_{\min }=-0.32$ e $\AA^{-3}$

Absolute structure: Flack (1983), 3784 Friedel pairs

Absolute structure parameter: 0.0 (12)

Fractional atomic coordinates and isotropic or equivalent isotropic displacement parameters $\left(\AA^{2}\right)$

\begin{tabular}{|c|c|c|c|c|}
\hline & $x$ & $y$ & $z$ & $U_{\text {iso }} * / U_{\text {eq }}$ \\
\hline $\mathrm{O} 1$ & 0.4378 (4) & $0.56200(8)$ & $0.5509(2)$ & 0.0232 \\
\hline $\mathrm{C} 2$ & $0.4241(7)$ & $0.59191(12)$ & $0.4802(3)$ & 0.0203 \\
\hline $\mathrm{O} 3$ & $0.2303(5)$ & $0.59922(8)$ & $0.3894(2)$ & 0.0247 \\
\hline H31 & $0.112(12)$ & $0.576(2)$ & $0.377(6)$ & $0.11(2)^{*}$ \\
\hline $\mathrm{C} 4$ & $0.6267(7)$ & $0.62630(11)$ & $0.4940(3)$ & 0.0221 \\
\hline $\mathrm{C} 5$ & $0.5727(6)$ & $0.65472(10)$ & $0.6024(3)$ & 0.0181 \\
\hline C6 & $0.7247(6)$ & $0.65288(11)$ & $0.7187(3)$ & 0.0196 \\
\hline $\mathrm{C} 7$ & $0.6735(6)$ & $0.67617(10)$ & $0.8260(3)$ & 0.0180 \\
\hline C8 & $0.4541(7)$ & $0.70264(11)$ & $0.8126(3)$ & 0.0197 \\
\hline C9 & $0.3957(7)$ & $0.72504(11)$ & $0.9208(3)$ & 0.0231 \\
\hline $\mathrm{C} 10$ & $0.5430(7)$ & $0.72134(11)$ & $1.0363(4)$ & 0.0241 \\
\hline O11 & $0.5058(5)$ & $0.74113(8)$ & $1.1475(2)$ & 0.0309 \\
\hline $\mathrm{C} 12$ & $0.2983(7)$ & $0.77030(12)$ & 1.1379 (4) & 0.0322 \\
\hline H123 & 0.3224 & 0.7929 & 1.0780 & $0.0478 *$ \\
\hline H121 & 0.3005 & 0.7822 & 1.2234 & $0.0477^{*}$ \\
\hline H122 & 0.1382 & 0.7559 & 1.1113 & $0.0472 *$ \\
\hline $\mathrm{C} 13$ & $0.7591(7)$ & 0.69497 (11) & 1.0509 (4) & 0.0257 \\
\hline C14 & $0.8229(7)$ & $0.67357(11)$ & $0.9476(3)$ & 0.0228 \\
\hline H141 & 0.9695 & 0.6573 & 0.9575 & $0.0265^{*}$ \\
\hline H131 & 0.8567 & 0.6924 & 1.1316 & $0.0301^{*}$ \\
\hline H91 & 0.2554 & 0.7415 & 0.9113 & $0.0267^{*}$ \\
\hline $\mathrm{C} 15$ & $0.3032(7)$ & $0.70457(11)$ & 0.6915 (3) & 0.0231 \\
\hline $\mathrm{C} 16$ & $0.3590(7)$ & $0.68113(11)$ & $0.5895(3)$ & 0.0249 \\
\hline H161 & 0.2532 & 0.6830 & 0.5093 & $0.0293^{*}$ \\
\hline H151 & 0.1610 & 0.7219 & 0.6811 & $0.0264 *$ \\
\hline H61 & 0.8674 & 0.6349 & 0.7284 & $0.0228 *$ \\
\hline $\mathrm{C} 17$ & $0.6435(7)$ & $0.64898(12)$ & $0.3674(3)$ & 0.0271 \\
\hline H172 & 0.7890 & 0.6669 & 0.3828 & $0.0399 *$ \\
\hline H173 & 0.4911 & 0.6650 & 0.3434 & $0.0395 *$ \\
\hline
\end{tabular}




\begin{tabular}{|c|c|c|c|c|}
\hline H171 & 0.6693 & 0.6285 & 0.3029 & $0.0389 *$ \\
\hline H41 & 0.7887 & 0.6126 & 0.5195 & $0.0241 *$ \\
\hline $\mathrm{O} 18$ & $0.6325(5)$ & $0.49432(8)$ & $-0.0209(2)$ & 0.0248 \\
\hline C19 & $0.7291(7)$ & $0.51165(11)$ & -0.1075 & 0.0179 \\
\hline N20 & $0.6560(6)$ & $0.50515(11)$ & $-0.2308(3)$ & 0.0216 \\
\hline H201 & $0.709(7)$ & $0.5204(12)$ & $-0.290(4)$ & $0.029(12)^{*}$ \\
\hline $\mathrm{H} 202$ & $0.516(8)$ & $0.4924(14)$ & $-0.252(4)$ & $0.051(15)^{*}$ \\
\hline C21 & $0.9489(6)$ & $0.54156(11)$ & -0.0742 & 0.0167 \\
\hline N22 & $1.0607(6)$ & $0.55501(9)$ & $-0.1726(3)$ & 0.0200 \\
\hline $\mathrm{C} 23$ & $1.2600(7)$ & $0.58056(11)$ & $-0.1446(3)$ & 0.0219 \\
\hline $\mathrm{C} 24$ & $1.3513(7)$ & $0.59343(12)$ & $-0.0212(4)$ & 0.0258 \\
\hline $\mathrm{C} 25$ & $1.2309(7)$ & $0.57978(11)$ & 0.0793 (3) & 0.0251 \\
\hline $\mathrm{C} 26$ & $1.0262(6)$ & $0.55282(10)$ & $0.0511(3)$ & 0.0195 \\
\hline H261 & 0.9419 & 0.5425 & 0.1159 & $0.0223 *$ \\
\hline $\mathrm{H} 251$ & 1.2883 & 0.5884 & 0.1638 & $0.0295^{*}$ \\
\hline $\mathrm{H} 241$ & 1.4920 & 0.6117 & -0.0074 & $0.0295^{*}$ \\
\hline $\mathrm{H} 231$ & 1.3371 & 0.5900 & -0.2134 & $0.0254^{*}$ \\
\hline $\mathrm{O} 27$ & $0.8720(4)$ & $0.54397(8)$ & $0.3544(2)$ & 0.0230 \\
\hline $\mathrm{C} 28$ & $0.8488(7)$ & $0.51366(11)$ & $0.4263(3)$ & 0.0196 \\
\hline N29 & $1.0064(6)$ & $0.50586(11)$ & $0.5322(3)$ & 0.0203 \\
\hline H291 & $1.132(7)$ & $0.5207(13)$ & $0.541(4)$ & $0.034(13)^{*}$ \\
\hline H292 & $0.983(6)$ & $0.4843(11)$ & $0.569(3)$ & $0.011(9)^{*}$ \\
\hline $\mathrm{C} 30$ & $0.6292(7)$ & $0.48402(11)$ & $0.3962(3)$ & 0.0190 \\
\hline N31 & $0.6001(5)$ & $0.45562(9)$ & $0.4862(3)$ & 0.0191 \\
\hline C32 & $0.4025(7)$ & $0.42970(11)$ & $0.4628(3)$ & 0.0224 \\
\hline C33 & $0.2291(7)$ & $0.43108(12)$ & 0.3515 & 0.0250 \\
\hline C34 & $0.2638(7)$ & $0.45985(12)$ & $0.2583(4)$ & 0.0263 \\
\hline $\mathrm{C} 35$ & $0.4681(7)$ & $0.48737(11)$ & $0.2803(3)$ & 0.0211 \\
\hline H351 & 0.4973 & 0.5073 & 0.2185 & $0.0243 *$ \\
\hline H341 & 0.1539 & 0.4607 & 0.1810 & $0.0306^{*}$ \\
\hline H331 & 0.0875 & 0.4125 & 0.3415 & $0.0296^{*}$ \\
\hline H321 & 0.3803 & 0.4092 & 0.5252 & $0.0273 *$ \\
\hline $\mathrm{O} 36$ & $0.2343(5)$ & $0.44737(8)$ & -0.0499 (2) & 0.0252 \\
\hline C37 & $0.1521(7)$ & $0.43264(11)$ & $-0.1638(3)$ & 0.0189 \\
\hline $\mathrm{O} 38$ & $0.2394(5)$ & $0.44237(9)$ & $-0.2598(2)$ & 0.0316 \\
\hline C39 & $-0.0700(7)$ & $0.40269(11)$ & $-0.1636(3)$ & 0.0220 \\
\hline $\mathrm{C} 40$ & $-0.0348(6)$ & $0.37457(11)$ & $-0.0465(3)$ & 0.0185 \\
\hline $\mathrm{C} 41$ & $-0.1834(6)$ & $0.37858(11)$ & $0.0474(3)$ & 0.0168 \\
\hline $\mathrm{C} 42$ & $-0.1412(6)$ & $0.35407(11)$ & 0.1608 & 0.0187 \\
\hline $\mathrm{C} 43$ & $0.0604(7)$ & $0.32507(11)$ & $0.1771(3)$ & 0.0183 \\
\hline $\mathrm{C} 44$ & $0.2075(7)$ & $0.32036(11)$ & $0.0757(3)$ & 0.0213 \\
\hline $\mathrm{C} 45$ & $0.1614(7)$ & $0.34455(11)$ & -0.0314 & 0.0216 \\
\hline H451 & 0.2674 & 0.3416 & -0.0956 & $0.0243^{*}$ \\
\hline H441 & 0.3385 & 0.3005 & 0.0844 & $0.0249 *$ \\
\hline $\mathrm{C} 46$ & $0.1149(7)$ & $0.30214(11)$ & 0.2935 & 0.0226 \\
\hline $\mathrm{C} 47$ & $-0.0292(7)$ & $0.30875(11)$ & 0.3903 (3) & 0.0234 \\
\hline O48 & $0.0091(6)$ & $0.28929(9)$ & $0.5078(2)$ & 0.0342 \\
\hline C49 & $0.2290(9)$ & $0.26351(13)$ & $0.5351(4)$ & 0.0422 \\
\hline
\end{tabular}




$\begin{array}{lllll}\text { H493 } & 0.2390 & 0.2529 & 0.6213 & 0.0627^{*} \\ \text { H492 } & 0.3818 & 0.2794 & 0.5279 & 0.0631^{*} \\ \text { H491 } & 0.2220 & 0.2398 & 0.4770 & 0.0627^{*} \\ \text { C50 } & -0.2351(7) & 0.33665(11) & 0.3730(4) & 0.0247 \\ \text { C51 } & -0.2910(7) & 0.35845(11) & 0.2618(4) & 0.0222 \\ \text { H511 } & -0.4230 & 0.3773 & 0.2516 & 0.0266^{*} \\ \text { H501 } & -0.3324 & 0.3407 & 0.4391 & 0.0295^{*} \\ \text { H461 } & 0.2439 & 0.2833 & 0.3032 & 0.0272^{*} \\ \text { H411 } & -0.3181 & 0.3975 & 0.0397 & 0.0200^{*} \\ \text { C52 } & -0.1228(8) & 0.37858(13) & -0.2901(3) & 0.0328 \\ \text { H523 } & -0.2754 & 0.3625 & -0.2899 & 0.0485^{*} \\ \text { H522 } & 0.0165 & 0.3595 & -0.2966 & 0.0488^{*} \\ \text { H521 } & -0.1405 & 0.3980 & -0.3621 & 0.0480^{*} \\ \text { H391 } & -0.2203 & 0.4198 & -0.1566 & 0.0260^{*} \\ \text { H361 } & 0.357(7) & 0.4642(13) & -0.053(4) & 0.033(12)^{*}\end{array}$

Atomic displacement parameters $\left(\AA^{2}\right)$

\begin{tabular}{|c|c|c|c|c|c|c|}
\hline & $U^{11}$ & $U^{22}$ & $U^{\beta 3}$ & $U^{12}$ & $U^{13}$ & $U^{23}$ \\
\hline $\mathrm{O} 1$ & $0.0257(14)$ & $0.0216(14)$ & $0.0228(13)$ & $-0.0041(11)$ & 0.0048 (11) & $0.0052(11)$ \\
\hline $\mathrm{C} 2$ & $0.025(2)$ & $0.0240(19)$ & $0.0137(17)$ & $0.0027(16)$ & $0.0097(15)$ & $-0.0076(14)$ \\
\hline $\mathrm{O} 3$ & $0.0281(15)$ & $0.0251(15)$ & $0.0202(14)$ & $-0.0033(12)$ & $0.0006(12)$ & $0.0032(11)$ \\
\hline $\mathrm{C} 4$ & $0.0169(19)$ & $0.028(2)$ & $0.022(2)$ & $-0.0025(16)$ & $0.0039(15)$ & $0.0009(15)$ \\
\hline $\mathrm{C} 5$ & $0.0240(19)$ & $0.0144(17)$ & $0.0170(18)$ & $-0.0040(15)$ & $0.0070(15)$ & $-0.0010(13)$ \\
\hline C6 & $0.0165(18)$ & $0.0166(18)$ & $0.027(2)$ & $-0.0021(15)$ & $0.0084(15)$ & $0.0023(15)$ \\
\hline C7 & $0.0175(19)$ & 0.0117 (17) & 0.0257 (19) & $-0.0062(14)$ & $0.0060(15)$ & $0.0039(14)$ \\
\hline $\mathrm{C} 8$ & $0.025(2)$ & $0.0132(17)$ & 0.0215 (19) & $-0.0050(15)$ & $0.0043(16)$ & $0.0010(14)$ \\
\hline C9 & $0.020(2)$ & $0.0188(19)$ & $0.030(2)$ & $0.0050(15)$ & 0.0048 (17) & $0.0001(16)$ \\
\hline C10 & 0.028 (2) & $0.0182(18)$ & $0.026(2)$ & $-0.0012(16)$ & $0.0041(17)$ & $-0.0025(15)$ \\
\hline O11 & $0.0407(17)$ & $0.0277(15)$ & $0.0241(15)$ & $0.0043(13)$ & $0.0041(13)$ & $-0.0043(11)$ \\
\hline $\mathrm{C} 12$ & $0.035(2)$ & $0.033(2)$ & $0.028(2)$ & $0.0005(19)$ & $0.0036(19)$ & $-0.0111(17)$ \\
\hline C13 & 0.029 (2) & $0.025(2)$ & $0.022(2)$ & $-0.0066(17)$ & $0.0006(17)$ & $0.0046(16)$ \\
\hline C14 & $0.024(2)$ & $0.0220(19)$ & $0.022(2)$ & $-0.0012(16)$ & $0.0004(16)$ & $-0.0005(15)$ \\
\hline C15 & $0.024(2)$ & $0.0162(18)$ & $0.029(2)$ & $0.0033(16)$ & $0.0036(16)$ & $0.0013(15)$ \\
\hline $\mathrm{C} 16$ & $0.024(2)$ & $0.024(2)$ & $0.025(2)$ & $-0.0036(17)$ & $-0.0030(16)$ & $-0.0007(16)$ \\
\hline C17 & $0.031(2)$ & $0.026(2)$ & $0.028(2)$ & $-0.0024(18)$ & $0.0139(17)$ & $0.0010(17)$ \\
\hline O18 & $0.0282(14)$ & $0.0277(14)$ & $0.0191(13)$ & $-0.0084(12)$ & $0.0061(11)$ & $0.0017(11)$ \\
\hline C19 & $0.0181(18)$ & $0.0142(16)$ & $0.0203(18)$ & $0.0054(15)$ & $-0.0008(15)$ & $0.0011(14)$ \\
\hline $\mathrm{N} 20$ & $0.0190(17)$ & $0.0285(19)$ & $0.0166(17)$ & $-0.0070(14)$ & $0.0003(14)$ & $0.0045(14)$ \\
\hline $\mathrm{C} 21$ & $0.0183(17)$ & $0.0137(16)$ & 0.0177 (17) & $0.0039(15)$ & $0.0008(14)$ & $-0.0015(14)$ \\
\hline N22 & $0.0264(17)$ & $0.0189(15)$ & $0.0156(15)$ & $0.0039(13)$ & $0.0055(13)$ & $0.0012(11)$ \\
\hline $\mathrm{C} 23$ & $0.024(2)$ & $0.0202(18)$ & $0.023(2)$ & $-0.0021(16)$ & $0.0073(16)$ & $0.0061(15)$ \\
\hline $\mathrm{C} 24$ & $0.019(2)$ & $0.0235(19)$ & $0.033(2)$ & $0.0002(16)$ & $-0.0006(17)$ & $-0.0013(17)$ \\
\hline $\mathrm{C} 25$ & $0.029(2)$ & $0.024(2)$ & $0.020(2)$ & $-0.0004(17)$ & -0.0049 (17) & $-0.0036(15)$ \\
\hline $\mathrm{C} 26$ & $0.0235(19)$ & $0.0160(18)$ & $0.0207(18)$ & $-0.0016(15)$ & $0.0090(15)$ & $0.0025(14)$ \\
\hline $\mathrm{O} 27$ & $0.0264(14)$ & $0.0236(13)$ & $0.0186(12)$ & $-0.0036(12)$ & $0.0015(11)$ & $0.0044(11)$ \\
\hline $\mathrm{C} 28$ & $0.028(2)$ & $0.0173(17)$ & $0.0150(18)$ & $0.0029(16)$ & $0.0070(15)$ & $-0.0035(14)$ \\
\hline N29 & $0.0242(18)$ & $0.0181(17)$ & $0.0193(17)$ & $-0.0052(14)$ & $0.0051(14)$ & $0.0048(13)$ \\
\hline
\end{tabular}




$\begin{array}{lllllll}\text { C30 } & 0.025(2) & 0.0174(18) & 0.0160(18) & 0.0008(15) & 0.0069(15) & -0.0045(14) \\ \mathrm{N} 31 & 0.0226(16) & 0.0162(15) & 0.0190(15) & 0.0016(13) & 0.0049(12) & -0.0021(12) \\ \text { C32 } & 0.032(2) & 0.0173(19) & 0.0198(19) & -0.0011(16) & 0.0112(17) & -0.0035(14) \\ \text { C33 } & 0.023(2) & 0.029(2) & 0.024(2) & -0.0071(17) & 0.0065(16) & -0.0108(16) \\ \text { C34 } & 0.024(2) & 0.035(2) & 0.0204(19) & 0.0023(18) & 0.0024(15) & -0.0072(17) \\ \text { C35 } & 0.024(2) & 0.026(2) & 0.0148(17) & -0.0011(16) & 0.0076(15) & 0.0000(15) \\ \text { O36 } & 0.0299(15) & 0.0287(15) & 0.0178(13) & -0.0131(13) & 0.0058(12) & 0.0001(11) \\ \text { C37 } & 0.0190(19) & 0.0138(17) & 0.023(2) & 0.0034(14) & 0.0003(15) & 0.0036(15) \\ \text { O38 } & 0.0361(16) & 0.0394(16) & 0.0201(13) & -0.0130(13) & 0.0074(12) & -0.0025(12) \\ \text { C39 } & 0.028(2) & 0.0198(19) & 0.0180(18) & 0.0004(16) & 0.0026(16) & 0.0015(14) \\ \text { C40 } & 0.0181(18) & 0.0134(17) & 0.0229(19) & -0.0062(15) & -0.0009(15) & 0.0000(14) \\ \text { C41 } & 0.0112(17) & 0.0152(17) & 0.0229(19) & 0.0010(14) & -0.0010(14) & -0.0018(14) \\ \text { C42 } & 0.0154(18) & 0.0206(18) & 0.0203(19) & -0.0074(15) & 0.0027(15) & -0.0002(14) \\ \text { C43 } & 0.0190(18) & 0.0170(18) & 0.0194(18) & -0.0039(15) & 0.0040(14) & -0.0016(14) \\ \text { C44 } & 0.0198(19) & 0.0155(17) & 0.028(2) & 0.0035(15) & 0.0030(16) & -0.0009(15) \\ \text { C45 } & 0.023(2) & 0.0210(19) & 0.0213(19) & -0.0013(16) & 0.0044(16) & -0.0017(15) \\ \text { C46 } & 0.026(2) & 0.0162(18) & 0.024(2) & 0.0000(15) & -0.0014(16) & 0.0031(15) \\ \text { C47 } & 0.031(2) & 0.0198(19) & 0.0181(18) & -0.0085(16) & -0.0019(16) & 0.0038(15) \\ \text { O48 } & 0.0523(18) & 0.0287(15) & 0.0210(14) & -0.0048(13) & 0.0027(13) & 0.0058(11) \\ \text { C49 } & 0.050(3) & 0.038(3) & 0.035(3) & -0.001(2) & -0.008(2) & 0.017(2) \\ \text { C50 } & 0.026(2) & 0.028(2) & 0.022(2) & -0.0090(17) & 0.0103(16) & -0.0051(16) \\ \text { C51 } & 0.0192(19) & 0.0184(18) & 0.029(2) & -0.0001(15) & 0.0045(17) & -0.0042(16) \\ \text { C52 } & 0.046(3) & 0.029(2) & 0.020(2) & -0.0103(19) & -0.0084(19) & 0.0057(17) \\ & & & & & & \end{array}$

Geometric parameters (A, $\stackrel{\circ}{)}$

\begin{tabular}{|c|c|c|c|}
\hline $\mathrm{O} 1-\mathrm{C} 2$ & $1.205(4)$ & $\mathrm{O} 27-\mathrm{C} 28$ & $1.244(4)$ \\
\hline $\mathrm{C} 2-\mathrm{O} 3$ & $1.320(4)$ & $\mathrm{C} 28-\mathrm{N} 29$ & $1.317(5)$ \\
\hline $\mathrm{C} 2-\mathrm{C} 4$ & $1.528(5)$ & $\mathrm{C} 28-\mathrm{C} 30$ & $1.499(5)$ \\
\hline $\mathrm{O} 3-\mathrm{H} 31$ & $0.97(6)$ & N29-H291 & $0.81(4)$ \\
\hline $\mathrm{C} 4-\mathrm{C} 5$ & $1.515(5)$ & N29-H292 & $0.81(3)$ \\
\hline $\mathrm{C} 4-\mathrm{C} 17$ & $1.528(5)$ & $\mathrm{C} 30-\mathrm{N} 31$ & $1.335(4)$ \\
\hline $\mathrm{C} 4-\mathrm{H} 41$ & 0.967 & $\mathrm{C} 30-\mathrm{C} 35$ & $1.389(5)$ \\
\hline $\mathrm{C} 5-\mathrm{C} 6$ & $1.367(5)$ & $\mathrm{N} 31-\mathrm{C} 32$ & $1.330(4)$ \\
\hline $\mathrm{C} 5-\mathrm{C} 16$ & $1.403(5)$ & C32-C33 & $1.381(5)$ \\
\hline C6-C7 & $1.408(5)$ & $\mathrm{C} 32-\mathrm{H} 321$ & 0.945 \\
\hline C6-H61 & 0.942 & C $33-\mathrm{C} 34$ & $1.374(5)$ \\
\hline $\mathrm{C} 7-\mathrm{C} 8$ & $1.428(5)$ & C $33-\mathrm{H} 331$ & 0.951 \\
\hline $\mathrm{C} 7-\mathrm{C} 14$ & 1.407 (5) & C34-C35 & $1.388(5)$ \\
\hline $\mathrm{C} 8-\mathrm{C} 9$ & $1.414(5)$ & C34-H341 & 0.930 \\
\hline $\mathrm{C} 8-\mathrm{C} 15$ & $1.405(5)$ & $\mathrm{C} 35-\mathrm{H} 351$ & 0.937 \\
\hline $\mathrm{C} 9-\mathrm{C} 10$ & $1.352(5)$ & $\mathrm{O} 36-\mathrm{C} 37$ & $1.302(4)$ \\
\hline C9-H91 & 0.904 & O36-H361 & $0.85(4)$ \\
\hline $\mathrm{C} 10-\mathrm{O} 11$ & $1.367(4)$ & $\mathrm{C} 37-\mathrm{O} 38$ & $1.209(4)$ \\
\hline $\mathrm{C} 10-\mathrm{C} 13$ & $1.413(5)$ & C37-C39 & $1.517(5)$ \\
\hline $\mathrm{O} 11-\mathrm{C} 12$ & $1.434(4)$ & C39-C40 & $1.513(5)$ \\
\hline $\mathrm{C} 12-\mathrm{H} 123$ & 0.977 & C39-C52 & $1.526(5)$ \\
\hline $\mathrm{C} 12-\mathrm{H} 121$ & 0.974 & С $39-\mathrm{H} 391$ & 0.978 \\
\hline
\end{tabular}




\begin{tabular}{|c|c|c|c|}
\hline $\mathrm{C} 12-\mathrm{H} 122$ & 0.970 & $\mathrm{C} 40-\mathrm{C} 41$ & $1.353(5)$ \\
\hline $\mathrm{C} 13-\mathrm{C} 14$ & $1.365(5)$ & $\mathrm{C} 40-\mathrm{C} 45$ & $1.407(5)$ \\
\hline $\mathrm{C} 13-\mathrm{H} 131$ & 0.931 & $\mathrm{C} 41-\mathrm{C} 42$ & $1.416(4)$ \\
\hline C14-H141 & 0.929 & $\mathrm{C} 41-\mathrm{H} 411$ & 0.931 \\
\hline $\mathrm{C} 15-\mathrm{C} 16$ & $1.373(5)$ & $\mathrm{C} 42-\mathrm{C} 43$ & $1.406(5)$ \\
\hline $\mathrm{C} 15-\mathrm{H} 151$ & 0.928 & $\mathrm{C} 42-\mathrm{C} 51$ & $1.420(5)$ \\
\hline C16-H161 & 0.946 & $\mathrm{C} 43-\mathrm{C} 44$ & $1.415(4)$ \\
\hline C17-H172 & 0.956 & $\mathrm{C} 43-\mathrm{C} 46$ & $1.420(5)$ \\
\hline C17-H173 & 0.960 & $\mathrm{C} 44-\mathrm{C} 45$ & $1.357(5)$ \\
\hline C17-H171 & 0.965 & $\mathrm{C} 44-\mathrm{H} 441$ & 0.936 \\
\hline $\mathrm{O} 18-\mathrm{C} 19$ & $1.236(4)$ & $\mathrm{C} 45-\mathrm{H} 451$ & 0.943 \\
\hline $\mathrm{C} 19-\mathrm{N} 20$ & $1.315(4)$ & $\mathrm{C} 46-\mathrm{C} 47$ & $1.372(5)$ \\
\hline $\mathrm{C} 19-\mathrm{C} 21$ & $1.508(5)$ & $\mathrm{C} 46-\mathrm{H} 461$ & 0.906 \\
\hline $\mathrm{N} 20-\mathrm{H} 201$ & $0.87(4)$ & $\mathrm{C} 47-\mathrm{O} 48$ & $1.371(4)$ \\
\hline N20-H202 & $0.85(4)$ & $\mathrm{C} 47-\mathrm{C} 50$ & $1.401(5)$ \\
\hline $\mathrm{C} 21-\mathrm{N} 22$ & $1.333(4)$ & $\mathrm{O} 48-\mathrm{C} 49$ & $1.423(5)$ \\
\hline $\mathrm{C} 21-\mathrm{C} 26$ & $1.370(4)$ & $\mathrm{C} 49-\mathrm{H} 493$ & 0.961 \\
\hline $\mathrm{N} 22-\mathrm{C} 23$ & $1.334(4)$ & $\mathrm{C} 49-\mathrm{H} 492$ & 0.967 \\
\hline $\mathrm{C} 23-\mathrm{C} 24$ & $1.380(5)$ & $\mathrm{C} 49-\mathrm{H} 491$ & 0.970 \\
\hline $\mathrm{C} 23-\mathrm{H} 231$ & 0.930 & $\mathrm{C} 50-\mathrm{C} 51$ & $1.355(5)$ \\
\hline $\mathrm{C} 24-\mathrm{C} 25$ & $1.380(5)$ & $\mathrm{C} 50-\mathrm{H} 501$ & 0.932 \\
\hline $\mathrm{C} 24-\mathrm{H} 241$ & 0.941 & $\mathrm{C} 51-\mathrm{H} 511$ & 0.918 \\
\hline $\mathrm{C} 25-\mathrm{C} 26$ & $1.384(5)$ & $\mathrm{C} 52-\mathrm{H} 523$ & 0.959 \\
\hline $\mathrm{C} 25-\mathrm{H} 251$ & 0.938 & C52-H522 & 0.967 \\
\hline C26-H261 & 0.927 & $\mathrm{C} 52-\mathrm{H} 521$ & 0.971 \\
\hline $\mathrm{O} 1-\mathrm{C} 2-\mathrm{O} 3$ & $123.9(3)$ & $\mathrm{O} 27-\mathrm{C} 28-\mathrm{N} 29$ & $123.7(3)$ \\
\hline $\mathrm{O} 1-\mathrm{C} 2-\mathrm{C} 4$ & $122.0(3)$ & $\mathrm{O} 27-\mathrm{C} 28-\mathrm{C} 30$ & $120.2(3)$ \\
\hline $\mathrm{O} 3-\mathrm{C} 2-\mathrm{C} 4$ & $114.0(3)$ & $\mathrm{N} 29-\mathrm{C} 28-\mathrm{C} 30$ & $116.1(3)$ \\
\hline $\mathrm{C} 2-\mathrm{O} 3-\mathrm{H} 31$ & $113(4)$ & $\mathrm{C} 28-\mathrm{N} 29-\mathrm{H} 291$ & $114(3)$ \\
\hline $\mathrm{C} 2-\mathrm{C} 4-\mathrm{C} 5$ & $107.2(3)$ & $\mathrm{C} 28-\mathrm{N} 29-\mathrm{H} 292$ & $116(2)$ \\
\hline $\mathrm{C} 2-\mathrm{C} 4-\mathrm{C} 17$ & $112.6(3)$ & H291-N29-H292 & $128(4)$ \\
\hline $\mathrm{C} 5-\mathrm{C} 4-\mathrm{C} 17$ & $114.3(3)$ & $\mathrm{C} 28-\mathrm{C} 30-\mathrm{N} 31$ & $116.3(3)$ \\
\hline $\mathrm{C} 2-\mathrm{C} 4-\mathrm{H} 41$ & 106.7 & $\mathrm{C} 28-\mathrm{C} 30-\mathrm{C} 35$ & $120.0(3)$ \\
\hline $\mathrm{C} 5-\mathrm{C} 4-\mathrm{H} 41$ & 108.5 & $\mathrm{~N} 31-\mathrm{C} 30-\mathrm{C} 35$ & $123.7(3)$ \\
\hline $\mathrm{C} 17-\mathrm{C} 4-\mathrm{H} 41$ & 107.2 & $\mathrm{C} 30-\mathrm{N} 31-\mathrm{C} 32$ & $117.3(3)$ \\
\hline $\mathrm{C} 4-\mathrm{C} 5-\mathrm{C} 6$ & $119.8(3)$ & $\mathrm{N} 31-\mathrm{C} 32-\mathrm{C} 33$ & $123.3(3)$ \\
\hline $\mathrm{C} 4-\mathrm{C} 5-\mathrm{C} 16$ & $121.6(3)$ & $\mathrm{N} 31-\mathrm{C} 32-\mathrm{H} 321$ & 118.3 \\
\hline $\mathrm{C} 6-\mathrm{C} 5-\mathrm{C} 16$ & $118.5(3)$ & $\mathrm{C} 33-\mathrm{C} 32-\mathrm{H} 321$ & 118.4 \\
\hline $\mathrm{C} 5-\mathrm{C} 6-\mathrm{C} 7$ & $122.5(3)$ & C $32-\mathrm{C} 33-\mathrm{C} 34$ & $119.0(4)$ \\
\hline $\mathrm{C} 5-\mathrm{C} 6-\mathrm{H} 61$ & 119.1 & $\mathrm{C} 32-\mathrm{C} 33-\mathrm{H} 331$ & 119.6 \\
\hline $\mathrm{C} 7-\mathrm{C} 6-\mathrm{H} 61$ & 118.5 & $\mathrm{C} 34-\mathrm{C} 33-\mathrm{H} 331$ & 121.4 \\
\hline $\mathrm{C} 6-\mathrm{C} 7-\mathrm{C} 8$ & $118.7(3)$ & $\mathrm{C} 33-\mathrm{C} 34-\mathrm{C} 35$ & $118.9(4)$ \\
\hline $\mathrm{C} 6-\mathrm{C} 7-\mathrm{C} 14$ & $123.2(3)$ & $\mathrm{C} 33-\mathrm{C} 34-\mathrm{H} 341$ & 120.7 \\
\hline $\mathrm{C} 8-\mathrm{C} 7-\mathrm{C} 14$ & $118.0(3)$ & $\mathrm{C} 35-\mathrm{C} 34-\mathrm{H} 341$ & 120.4 \\
\hline $\mathrm{C} 7-\mathrm{C} 8-\mathrm{C} 9$ & $119.2(3)$ & $\mathrm{C} 30-\mathrm{C} 35-\mathrm{C} 34$ & $117.8(3)$ \\
\hline $\mathrm{C} 7-\mathrm{C} 8-\mathrm{C} 15$ & $117.8(3)$ & $\mathrm{C} 30-\mathrm{C} 35-\mathrm{H} 351$ & 121.2 \\
\hline $\mathrm{C} 9-\mathrm{C} 8-\mathrm{C} 15$ & $123.0(3)$ & $\mathrm{C} 34-\mathrm{C} 35-\mathrm{H} 351$ & 121.0 \\
\hline
\end{tabular}




\begin{tabular}{|c|c|}
\hline $\mathrm{C} 8-\mathrm{C} 9-\mathrm{C} 10$ & $120.9(3)$ \\
\hline $\mathrm{C} 8-\mathrm{C} 9-\mathrm{H} 91$ & 118.4 \\
\hline $\mathrm{C} 10-\mathrm{C} 9-\mathrm{H} 91$ & 120.7 \\
\hline $\mathrm{C} 9-\mathrm{C} 10-\mathrm{O} 11$ & $126.3(3)$ \\
\hline $\mathrm{C} 9-\mathrm{C} 10-\mathrm{C} 13$ & $120.4(3)$ \\
\hline $\mathrm{O} 11-\mathrm{C} 10-\mathrm{C} 13$ & $113.3(3)$ \\
\hline $\mathrm{C} 10-\mathrm{O} 11-\mathrm{C} 12$ & $116.3(3)$ \\
\hline $\mathrm{O} 11-\mathrm{C} 12-\mathrm{H} 123$ & 110.8 \\
\hline $\mathrm{O} 11-\mathrm{C} 12-\mathrm{H} 121$ & 106.3 \\
\hline $\mathrm{H} 123-\mathrm{C} 12-\mathrm{H} 121$ & 108.7 \\
\hline $\mathrm{O} 11-\mathrm{C} 12-\mathrm{H} 122$ & 110.2 \\
\hline $\mathrm{H} 123-\mathrm{C} 12-\mathrm{H} 122$ & 110.6 \\
\hline $\mathrm{H} 121-\mathrm{C} 12-\mathrm{H} 122$ & 110.2 \\
\hline $\mathrm{C} 10-\mathrm{C} 13-\mathrm{C} 14$ & $120.0(4)$ \\
\hline $\mathrm{C} 10-\mathrm{C} 13-\mathrm{H} 131$ & 119.2 \\
\hline $\mathrm{C} 14-\mathrm{C} 13-\mathrm{H} 131$ & 120.7 \\
\hline $\mathrm{C} 7-\mathrm{C} 14-\mathrm{C} 13$ & $121.4(4)$ \\
\hline $\mathrm{C} 7-\mathrm{C} 14-\mathrm{H} 141$ & 119.3 \\
\hline $\mathrm{C} 13-\mathrm{C} 14-\mathrm{H} 141$ & 119.3 \\
\hline $\mathrm{C} 8-\mathrm{C} 15-\mathrm{C} 16$ & $121.7(4)$ \\
\hline $\mathrm{C} 8-\mathrm{C} 15-\mathrm{H} 151$ & 118.8 \\
\hline $\mathrm{C} 16-\mathrm{C} 15-\mathrm{H} 151$ & 119.5 \\
\hline $\mathrm{C} 5-\mathrm{C} 16-\mathrm{C} 15$ & $120.8(3)$ \\
\hline $\mathrm{C} 5-\mathrm{C} 16-\mathrm{H} 161$ & 119.5 \\
\hline $\mathrm{C} 15-\mathrm{C} 16-\mathrm{H} 161$ & 119.7 \\
\hline $\mathrm{C} 4-\mathrm{C} 17-\mathrm{H} 172$ & 106.3 \\
\hline $\mathrm{C} 4-\mathrm{C} 17-\mathrm{H} 173$ & 109.3 \\
\hline $\mathrm{H} 172-\mathrm{C} 17-\mathrm{H} 173$ & 110.8 \\
\hline $\mathrm{C} 4-\mathrm{C} 17-\mathrm{H} 171$ & 108.8 \\
\hline $\mathrm{H} 172-\mathrm{C} 17-\mathrm{H} 171$ & 109.4 \\
\hline H173-C17-H171 & 112.1 \\
\hline $\mathrm{O} 18-\mathrm{C} 19-\mathrm{N} 20$ & $124.0(3)$ \\
\hline $\mathrm{O} 18-\mathrm{C} 19-\mathrm{C} 21$ & $120.0(3)$ \\
\hline $\mathrm{N} 20-\mathrm{C} 19-\mathrm{C} 21$ & $116.0(3)$ \\
\hline $\mathrm{C} 19-\mathrm{N} 20-\mathrm{H} 201$ & $123(3)$ \\
\hline $\mathrm{C} 19-\mathrm{N} 20-\mathrm{H} 202$ & $117(3)$ \\
\hline $\mathrm{H} 201-\mathrm{N} 20-\mathrm{H} 202$ & $116(4)$ \\
\hline $\mathrm{C} 19-\mathrm{C} 21-\mathrm{N} 22$ & $116.0(3)$ \\
\hline $\mathrm{C} 19-\mathrm{C} 21-\mathrm{C} 26$ & $120.2(3)$ \\
\hline $\mathrm{N} 22-\mathrm{C} 21-\mathrm{C} 26$ & $123.7(3)$ \\
\hline $\mathrm{C} 21-\mathrm{N} 22-\mathrm{C} 23$ & $116.9(3)$ \\
\hline $\mathrm{N} 22-\mathrm{C} 23-\mathrm{C} 24$ & $123.3(3)$ \\
\hline $\mathrm{N} 22-\mathrm{C} 23-\mathrm{H} 231$ & 116.7 \\
\hline $\mathrm{C} 24-\mathrm{C} 23-\mathrm{H} 231$ & 120.0 \\
\hline $\mathrm{C} 23-\mathrm{C} 24-\mathrm{C} 25$ & $119.1(4)$ \\
\hline $\mathrm{C} 23-\mathrm{C} 24-\mathrm{H} 241$ & 119.5 \\
\hline $\mathrm{C} 25-\mathrm{C} 24-\mathrm{H} 241$ & 121.4 \\
\hline $\mathrm{C} 24-\mathrm{C} 25-\mathrm{C} 26$ & $117.8(3)$ \\
\hline
\end{tabular}

\begin{tabular}{|c|c|}
\hline $\mathrm{C} 37-\mathrm{O} 36-\mathrm{H} 361$ & $111(3)$ \\
\hline $\mathrm{O} 36-\mathrm{C} 37-\mathrm{O} 38$ & $123.8(3)$ \\
\hline $\mathrm{O} 36-\mathrm{C} 37-\mathrm{C} 39$ & $112.6(3)$ \\
\hline $\mathrm{O} 38-\mathrm{C} 37-\mathrm{C} 39$ & $123.5(3)$ \\
\hline $\mathrm{C} 37-\mathrm{C} 39-\mathrm{C} 40$ & $111.6(3)$ \\
\hline $\mathrm{C} 37-\mathrm{C} 39-\mathrm{C} 52$ & $111.3(3)$ \\
\hline $\mathrm{C} 40-\mathrm{C} 39-\mathrm{C} 52$ & $113.3(3)$ \\
\hline С $37-\mathrm{C} 39-\mathrm{H} 391$ & 106.9 \\
\hline $\mathrm{C} 40-\mathrm{C} 39-\mathrm{H} 391$ & 106.0 \\
\hline $\mathrm{C} 52-\mathrm{C} 39-\mathrm{H} 391$ & 107.2 \\
\hline $\mathrm{C} 39-\mathrm{C} 40-\mathrm{C} 41$ & $121.3(3)$ \\
\hline $\mathrm{C} 39-\mathrm{C} 40-\mathrm{C} 45$ & $119.9(3)$ \\
\hline $\mathrm{C} 41-\mathrm{C} 40-\mathrm{C} 45$ & $118.7(3)$ \\
\hline $\mathrm{C} 40-\mathrm{C} 41-\mathrm{C} 42$ & $121.5(3)$ \\
\hline $\mathrm{C} 40-\mathrm{C} 41-\mathrm{H} 411$ & 121.2 \\
\hline $\mathrm{C} 42-\mathrm{C} 41-\mathrm{H} 411$ & 117.3 \\
\hline $\mathrm{C} 41-\mathrm{C} 42-\mathrm{C} 43$ & $119.5(3)$ \\
\hline $\mathrm{C} 41-\mathrm{C} 42-\mathrm{C} 51$ & $122.4(3)$ \\
\hline $\mathrm{C} 43-\mathrm{C} 42-\mathrm{C} 51$ & $118.1(3)$ \\
\hline $\mathrm{C} 42-\mathrm{C} 43-\mathrm{C} 44$ & $118.0(3)$ \\
\hline $\mathrm{C} 42-\mathrm{C} 43-\mathrm{C} 46$ & $120.1(3)$ \\
\hline $\mathrm{C} 44-\mathrm{C} 43-\mathrm{C} 46$ & $121.9(3)$ \\
\hline $\mathrm{C} 43-\mathrm{C} 44-\mathrm{C} 45$ & $120.7(3)$ \\
\hline $\mathrm{C} 43-\mathrm{C} 44-\mathrm{H} 441$ & 118.7 \\
\hline $\mathrm{C} 45-\mathrm{C} 44-\mathrm{H} 441$ & 120.6 \\
\hline $\mathrm{C} 40-\mathrm{C} 45-\mathrm{C} 44$ & $121.6(3)$ \\
\hline $\mathrm{C} 40-\mathrm{C} 45-\mathrm{H} 451$ & 119.7 \\
\hline $\mathrm{C} 44-\mathrm{C} 45-\mathrm{H} 451$ & 118.7 \\
\hline $\mathrm{C} 43-\mathrm{C} 46-\mathrm{C} 47$ & $119.5(3)$ \\
\hline $\mathrm{C} 43-\mathrm{C} 46-\mathrm{H} 461$ & 119.8 \\
\hline $\mathrm{C} 47-\mathrm{C} 46-\mathrm{H} 461$ & 120.6 \\
\hline $\mathrm{C} 46-\mathrm{C} 47-\mathrm{O} 48$ & $124.8(3)$ \\
\hline $\mathrm{C} 46-\mathrm{C} 47-\mathrm{C} 50$ & $120.5(3)$ \\
\hline $\mathrm{O} 48-\mathrm{C} 47-\mathrm{C} 50$ & $114.6(3)$ \\
\hline $\mathrm{C} 47-\mathrm{O} 48-\mathrm{C} 49$ & $117.1(3)$ \\
\hline $\mathrm{O} 48-\mathrm{C} 49-\mathrm{H} 493$ & 109.1 \\
\hline $\mathrm{O} 48-\mathrm{C} 49-\mathrm{H} 492$ & 110.7 \\
\hline $\mathrm{H} 493-\mathrm{C} 49-\mathrm{H} 492$ & 108.9 \\
\hline $\mathrm{O} 48-\mathrm{C} 49-\mathrm{H} 491$ & 111.5 \\
\hline $\mathrm{H} 493-\mathrm{C} 49-\mathrm{H} 491$ & 108.1 \\
\hline $\mathrm{H} 492-\mathrm{C} 49-\mathrm{H} 491$ & 108.4 \\
\hline $\mathrm{C} 47-\mathrm{C} 50-\mathrm{C} 51$ & $120.6(3)$ \\
\hline $\mathrm{C} 47-\mathrm{C} 50-\mathrm{H} 501$ & 119.7 \\
\hline $\mathrm{C} 51-\mathrm{C} 50-\mathrm{H} 501$ & 119.8 \\
\hline $\mathrm{C} 42-\mathrm{C} 51-\mathrm{C} 50$ & $121.1(3)$ \\
\hline $\mathrm{C} 42-\mathrm{C} 51-\mathrm{H} 511$ & 118.4 \\
\hline $\mathrm{C} 50-\mathrm{C} 51-\mathrm{H} 511$ & 120.5 \\
\hline C $39-\mathrm{C} 52-\mathrm{H} 523$ & 108.5 \\
\hline
\end{tabular}


supporting information

$\begin{array}{llll}\mathrm{C} 24-\mathrm{C} 25-\mathrm{H} 251 & 120.6 & \mathrm{C} 39-\mathrm{C} 52-\mathrm{H} 522 & 109.3 \\ \mathrm{C} 26-\mathrm{C} 25-\mathrm{H} 251 & 121.6 & \mathrm{H} 523-\mathrm{C} 52-\mathrm{H} 522 & 108.6 \\ \mathrm{C} 25-\mathrm{C} 26-\mathrm{C} 21 & 119.1(3) & \mathrm{C} 39-\mathrm{C} 52-\mathrm{H} 521 & 110.0 \\ \mathrm{C} 25-\mathrm{C} 26-\mathrm{H} 261 & 120.6 & \mathrm{H} 523-\mathrm{C} 52-\mathrm{H} 521 & 110.8 \\ \mathrm{C} 21-\mathrm{C} 26-\mathrm{H} 261 & 120.2 & \mathrm{H} 522-\mathrm{C} 52-\mathrm{H} 521 & 109.6\end{array}$

Hydrogen-bond geometry $\left(\AA,{ }^{\circ}\right)$

\begin{tabular}{lllll}
\hline$D-\mathrm{H} \cdots A$ & $D-\mathrm{H}$ & $\mathrm{H} \cdots A$ & $D \cdots A$ & $D-\mathrm{H} \cdots A$ \\
\hline $\mathrm{O} 3-\mathrm{H} 31 \cdots \mathrm{O} 27^{\mathrm{i}}$ & 0.969 & 1.621 & $2.579(5)$ & $169(6)$ \\
$\mathrm{O} 3-\mathrm{H} 31 \cdots \mathrm{C} 28^{\mathrm{i}}$ & 0.969 & 2.526 & $3.452(5)$ & $160(5)$ \\
$\mathrm{N} 20-\mathrm{H} 201 \cdots \mathrm{O} 1^{\mathrm{ii}}$ & 0.866 & 2.437 & $3.022(5)$ & $125(3)$ \\
$\mathrm{N} 20-\mathrm{H} 202 \cdots \mathrm{O} 38$ & 0.848 & 2.161 & $2.965(5)$ & $158(4)$ \\
$\mathrm{C} 26-\mathrm{H} 261 \cdots \mathrm{O} 27$ & 0.93 & 2.58 & $3.412(5)$ & 149 \\
$\mathrm{C} 25-\mathrm{H} 251 \cdots \mathrm{O} 33^{\mathrm{iii}}$ & 0.94 & 2.46 & $3.317(5)$ & 152 \\
$\mathrm{~N} 29-\mathrm{H} 291 \cdots \mathrm{O} 1^{\mathrm{iii}}$ & 0.811 & 2.082 & $2.890(5)$ & $175(4)$ \\
$\mathrm{N} 29-\mathrm{H} 292 \cdots \mathrm{O} 38^{\mathrm{iv}}$ & 0.806 & 2.486 & $3.104(5)$ & $135(3)$ \\
$\mathrm{C} 34-\mathrm{H} 341 \cdots \mathrm{O} 36$ & 0.93 & 2.56 & $3.244(5)$ & 131 \\
$\mathrm{O} 36-\mathrm{H} 361 \cdots \mathrm{O} 18$ & 0.846 & 1.742 & $2.572(5)$ & $166(4)$
\end{tabular}

Symmetry codes: (i) $x-1, y, z$; (ii) $x, y, z-1$; (iii) $x+1, y, z$; (iv) $x+1, y, z+1$. 